DANUTA MISIUDA

Hrvatski restauratorski zavod

Odjel za štuko, Zagreb

dmisiuda@h-r-z.hr

TEODORA KUČINAC

Hrvatski restauratorski zavod

Odjel za graditeljsko nasljeđe, Zagreb

tkucinac@h-r-z.hr
Primljeno: 06. 03. 2019.

Prihvaćeno: 6. 11. 2019.

DOI: $10.21857 / 9 \mathrm{e} 31 \mathrm{lhnz} 4 \mathrm{~m}$

\title{
CRKVA SV. FLORIJANA U VARAŽDINU. REZULTATI KONZERVATORSKO - RESTAURATORSKIH ISTRAŽIVANJA I PREGLED RADOVA (1992. - 2017.)
}

Jednobrodna crkva sv. Florijana, smještena na povišenom platou na sjevernom rubu staroga grada Varaždina, čuva vrijedan, kompletno sačuvan inventar iz doba baroka. $U$ članku se prikazuje kronologija, valorizacija i atribucija gradnje i opreme crkve te pregled konzervatorsko-restauratorskih radova na pročeljima i u unutrašnjosti. Istraživanje arhivske dokumentacije dalo je nove podatke o opremi prvotne kapele iz 17. stoljeća, dok su konzervatorsko-restauratorska istraživanja slojeva u unutrašnjosti potvrdila pretpostavku atribucije zidnog oslika Blažu Gruberu i time proširila opus navedenog autora. U unutrašnjosti je obnovljena oprema i slikana dekoracija iz 1738., dok su oltari i propovjedaonica ostali u zatečenom stanju obnove iz 1870. godine. 


\section{KRONOLOGIJA, VALORIZACIJA I ATRIBUCIJA GRADNJE I OPREME}

U sklopu konzervatorsko-restauratorskih istraživanja i izrade dokumentacije za cjelovitu obnovu kapele sv. Florijana obrađena je relevantna literatura, ponajviše radovi povjesničara umjetnosti dr. Ivy Lentić Kugli i dr. Ive Lentića, publicirani u Vijestima muzealaca i konzervatora iz 60-tih i 70-tih godina prošlog stoljeća. $U$ tim su člancima objavljeni brojni podaci iz Državnog arhiva grada Varaždina na temelju kojih je ustanovljena kronologija gradnje kapele kao i imena pojedinih majstora - graditelja, klesara, stolara, slikara - vezanih uz izgradnju i opremanje unutrašnjosti. Obrađeni su također i protokoli kanonskih vizitacija Arhiđakonata varaždinskog iz 17., 18. i 19. st. koji upotpunjuju ranije poznate podatke.

Prva kapela sv. Florijana, ponajviše poznatog kao zaštitnika od požara, ali i kao zaštitnika pivara, bačvara, dimnjačara, vatrogasaca i sapunara podignuta je zaslugom varaždinskih obrtnika između 1669. i 1672.g. u sjevernom predgrađu, uz gradsku prometnicu via fossata ambiens, koja prati bedeme oko utvrđenja varaždinskog Starog grada. ${ }^{1}$

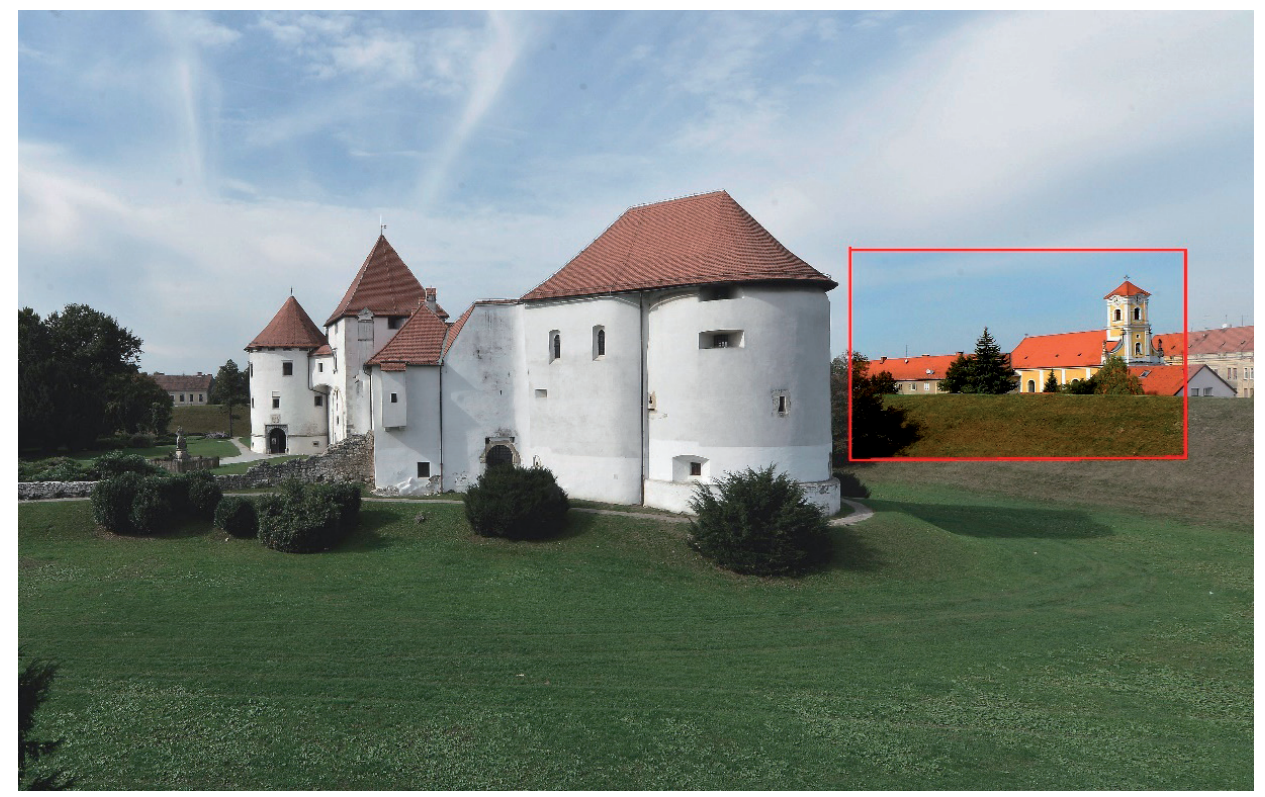

Slika 1. Pozicija crkve sv. Florijana u odnosu na Stari grad

1 Ivy LENTIĆ KUGLI: „Varaždin, povijesna urbana cjelina grada” Zagreb, 1977., 39.-40. 
Protokoli kanonskih vizitacija iz posljednje četvrtine 17. st. uz titular kapele redovito ističu i njezinu lokaciju (...) in suburbio civitatis (...) kao i to da je filijala župne crkve Sv. Nikole. Podaci iz istih izvora omogućuju da s dosta pojedinosti rekonstruiramo izgled te prvotne kapele.

Bila je to jednobrodna drvena crkvica s oslikanim drvenim tabulatom te drvenim trijemom i tornjićem, podignuta na zidanim temeljima. Krov je bio pokriven hrastovom šindrom. Izvana i iznutra zidovi su bili ožbukani i obijeljeni, pod kapele popločen je kamenom, a pod trijema opekom. U kapeli je bio jedan oltar, a još dva manja nalazila su se u trijemu. Uokolo bilo je groblje okruženo drvenom ogradom. ${ }^{2}$

Protokol vizitacije iz 1688. godine prvi put spominje orijentaciju kapele, navodeći da su sa zapadne strane glavna vrata ispred kojih je trijem. Saznajemo tako da je prva kapela sv. Florijana bila orijentirana na uobičajeni način, tj. da je svetište na istočnoj, a ulaz na zapadnoj strani, ${ }^{3}$ za razliku od sadašnje kapele, koja je orijentirana upravo suprotno. Taj podatak upućuje na određene promjene u urbanističkom smislu. Godine 1733. drvena je kapela srušena i započinje zidanje nove koja stoji i danas. Protokol kanonske vizitacije iz te godine precizno navodi da je kapela ponovno podignuta, da je zidana i nadsvođena. ${ }^{4}$

2 Protokoli kanonskih vizitacija Arhiđakonata varaždinskog:

- knj. 161/II, 1672., 44. "Capela S. Floriani Martyris in Fossa... visitata... hoc Capella est lignea tabulatum habet depictum, porticum cum tabulato depicto... campana 1, in turri lignea... tecto bono ex asseribus querciensis"

- knj 161/II, 1675. 119. "Capela S. Floriani in Fossa filialis ad S. Nicolai: tota llignea, tabulatum habet depictum, porticum in quo etiam est tabulatum depictum... habet Altare 1... in Atrio depictum... in Atrio Altaria 2..."

- knj. 162/III, 1678., 48.-49. "Capella S. Floriani... capella hoc lignea,... commode et proportionaliter alta tabulatum asseribus opere arculario eleboratum, simplici colore tinctum parietes habet bonos ab intro et extra incrustata et dealbata, pavimentum non stratum, porta habet una cum bona clausura, desuper turricula lignea erecta... ante fores porticum spaciosa, asseribus bene clausa... tabulatum habet uti capella..."

"Coemeterium capellae cintignum asseribus cinctum..."

- knj. 163/IV, 1683.,43. "Capella S. Floriani in Fossa Filialis ad S. Nicolaum... visitavi Capellam S. Floriani quae in anno Domini 1672 ex fundamentis est erecta, tota lignea... ipsus fundamentis quod ex muro est. Eiusdem parietes interno et externo coemento sunt incrustatis; eiusdem tabulatum est ligneum depictum, pavimentum lapide quadrato stratum; atrium ligneum cum taulato decento depicto, pavimento lateribus strato; habent in eodem attrio duo Altaria murata... supra eodem atrium est turricula lignea... tectum Capellae et Atrii sat bonum, coementerium bene assertibus cinctum...".

3 Protokoli..., knj 164/V, 1688. 56.-57. “... visitavi Capellam S. Floriani in Fossa fillialem S. Nicolai Varasdini, quam repesi in fundamentis murata et supra ex roboribus constructa, dealbata et bene incrustata, sub tabulato operis arularij depictum, lateribus strata et sub bono tecto ex asseribus quarcienis, ad occidentem ante portam Capella habet porticum, sub tabulato arcularij operis bene depictum,... item supra porta praescripta Capella habet turricula lignea..."

4 Protokoli..., knj 167/VIII, 1733., 387. "... visitavi Capellam S. Floriani Martyris in Fossa civitatis fillialem S. Nicolai Eppi et confessoris Varasdini, qua AD NOVUM AEDIFICATA ET SUB FORNICEM POSIT..." 


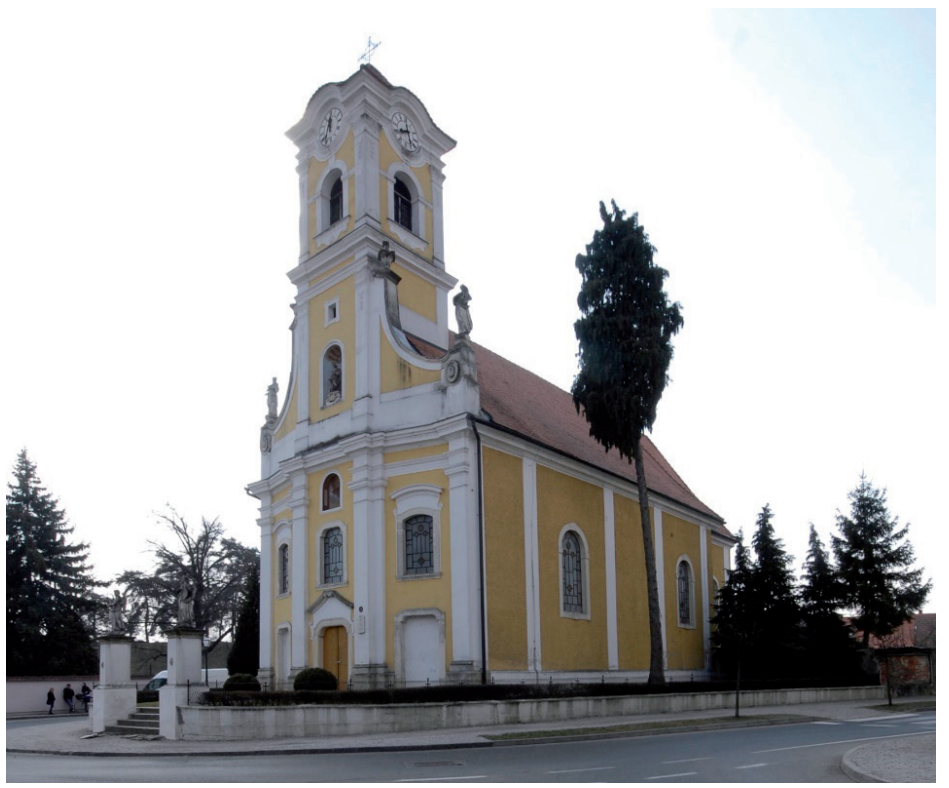

Slika 2. Pogled na crkvu sa sjeveroistoka

Tijekom konzervatorsko-restauratorskih istraživanja koje je u listopadu 1997. godine provodio Hrvatski restauratorski zavod na trijumfalnom je luku pronađen natpis: IN HONOREM SANCTI FLORIANI ET MARTIRIS HAEC AECCLESIA AEDIFICATA EST ANNO DNI 1738. (U ČAST SV. FLORIJANA I MUČENIKA OVA CRKVA PODIGNUTA JE GODINE GOSPODNJE 1738.)



Slika 3. Natpis na trijumfalnom luku 
Natpis se zacijelo odnosi na završetak izgradnje kapele, premda, prema sačuvanim dokumentima, svi radovi nisu bili potpuno završeni. Vizitacija iz 1748. g. bilježi da kapela izvana još nije dovršena, ali i naglašava osobitu plemenitost i ljepotu unutrašnjosti. ${ }^{5}$ Tek vizitacija iz 1752 . godine navodi da je kapela izvana ožbukana. ${ }^{6}$

Četrdesetih godina 18. st. kapela je opremljena vrijednim drvorezbarskim inventarom: glavni oltar sv. Florijana, bočni oltari sv. Apolonije i sv. Lucije, propovjedaonica te dva niza klupa sačuvani su, premda ponešto preinačeni, do danas. Arhivski dokumenti - ugovori i računi - vezani uz radove na crkvenom inventaru izdvajaju imena dvojice od mnogobrojnih majstora. Mathiasa Saurera ${ }^{7}$, stolara i Blaža Grubera ${ }^{8}$, slikara, polikromatora i pozlatara.

Vizitacija iz 1755. godine opširno opisuje sada već potpuno dovršenu kapelu: čitava je od temelja zidana, nadsvođena, popločena kamenim pločama, krov je pokriven hrastovom šindrom, a drveni je toranj ukrašen križem. Nad glavnim je vratima prostrani zidani kor s orguljama. ${ }^{9}$ Vizitacija iz 1771 . godine prvi put spominje da je kapela prekrivena crijepom i opisuje je kao prostranu i vrlo lijepu. ${ }^{10}$

Godine 1773. graditelj Erber gradi kriptu ispod kapele, ${ }^{11}$ a klesarske radove izvodi Johann Michael Taxner. ${ }^{12}$ Narednih godina Erber radi projekt i započinje izgradnju Xenodochia (ubožnice) ${ }^{13}$ prislonjenog uz južnu i zapadnu stranu svetišta kapele, a u čijem je sklopu i nova sakristija. Krajem 1775. godine završena je nova sakristija, koja je spajala Xenodochij i kapelu. ${ }^{14}$

5 Protokoli..., knj. 169/X, 1748., 18.: "De Capella S. Floriani... hoc capella necdum est perfecta ad foris... singular nobilia et pulchris tota quanta capella..."

6 Protokoli..., knj. 169/X, 1752., 57.: "De Capella S. Floriani... hanc Capella in Fossa Civitatis visitavi, quod mundam repesi, hoc anno a foris incrustata est..."

7 Ivo LENTIĆ," Varaždinski stolarski majstor Mathias Saurer", VMKH, Zagreb, 1968., br. 1.

8 I. LENTIĆ KUGLI, „Blasius Gruber pictor varasdiensis“, VMKH, Zagreb, 1970., br. 1-2, 13.-20.

9 Protokoli..., knj. 169/X, 1755., 80-81... “... visitavi Capellam Sancti Floriani Martyris Fillialem S. Nicolai Eppi et Confessoris quod repesi totam a fundamentis muratam, totam sub fornice, totam lapidibus quadro stratam, sub bono tecto... ad portam eiusdem maiorem Chorus largos muratus in quo est organum, in superfice Tecti Turris est lignea, sub tecto asseribus querciensis bono et crucem in superfice..."

10 Protokoli..., knj. 170/XI a, 1771., 71... "De Capella Scti Floriani... visitavi capellam in suburbia collocatum ex muro constructam, inbricibus tectam, amplam satis pulchram..."

11 I. LENTIĆ KUGLI, Varaždinski graditelji i zidari 1700-1850, Zagreb, 1981., 27.; podaci iz dokumenta iz Historijskog arhiva Varaždin - fond Arhiva grada Varaždina 1 -1, CV-77.

12 I LENTIĆ KUGLI, isto, 27.

13 I. LENTIĆ KUGLI, isto, 27.

14 I. LENTIĆ KUGLI, isto, 28., podaci iz dokumenta iz HAV, fond AGV 1-1, CX VIII-64, I-1, CX. 
U velikom požaru koji je 1776. godine zadesio grad Varaždin stradao je i drveni toranj nad glavnim pročeljem kapele sv. Florijana. Slijedeće godine započinje izgradnja novog tornja, ${ }^{15}$ a vizitacija iz 1780 . godine spominje da je podignut u osi glavnog pročelja i ukrašen slikom B. D. Marije. ${ }^{16}$

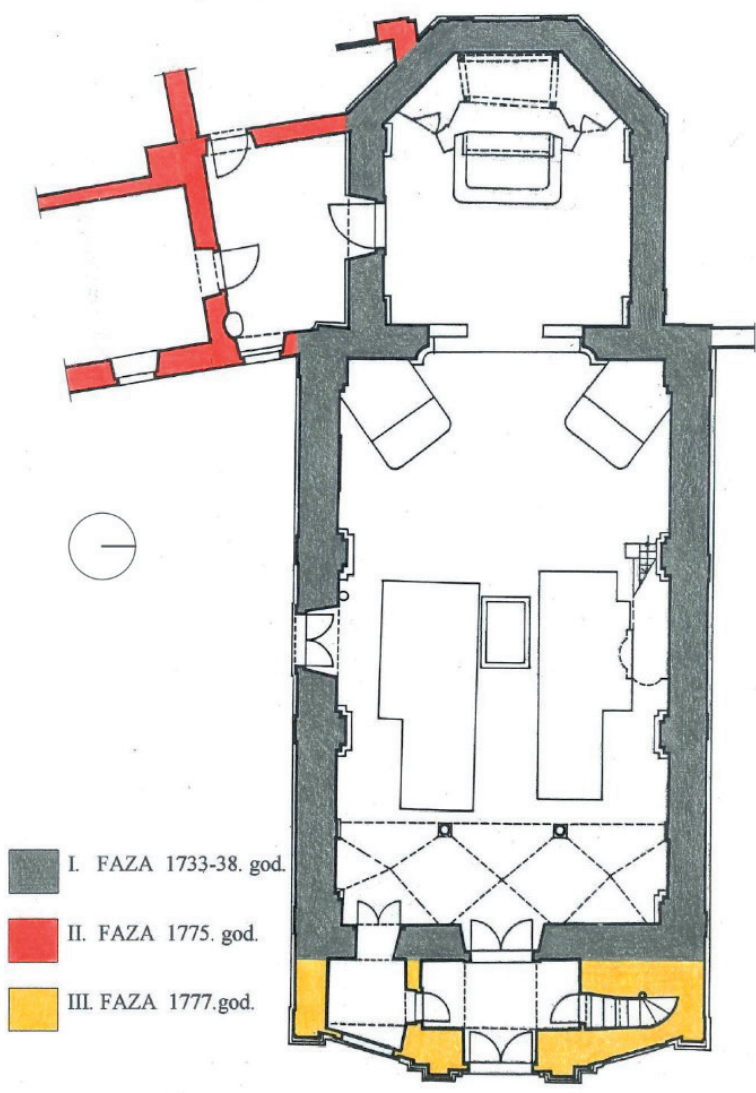

Slika 4. Tlocrtni prikaz faza gradnje kapele i Xenodochia

15 I. LENTIĆ KUGLI, isto, 32., podatak iz dokumentacije Župnog dvora Sv. Nikole u Varaždinu.

16 Protokoli..., knj. 170/XI a, 1780., 265.: „De Capella S. Floriani... vero noviter adjecta turri... cum imago B. V. Mariae..." 
Glavno pročelje je ukrašeno kamenim polikromiranim kipom sv. Florijana u niši tornja te kipovima svetih mučenica Apolonije i Lucije na zabatima.

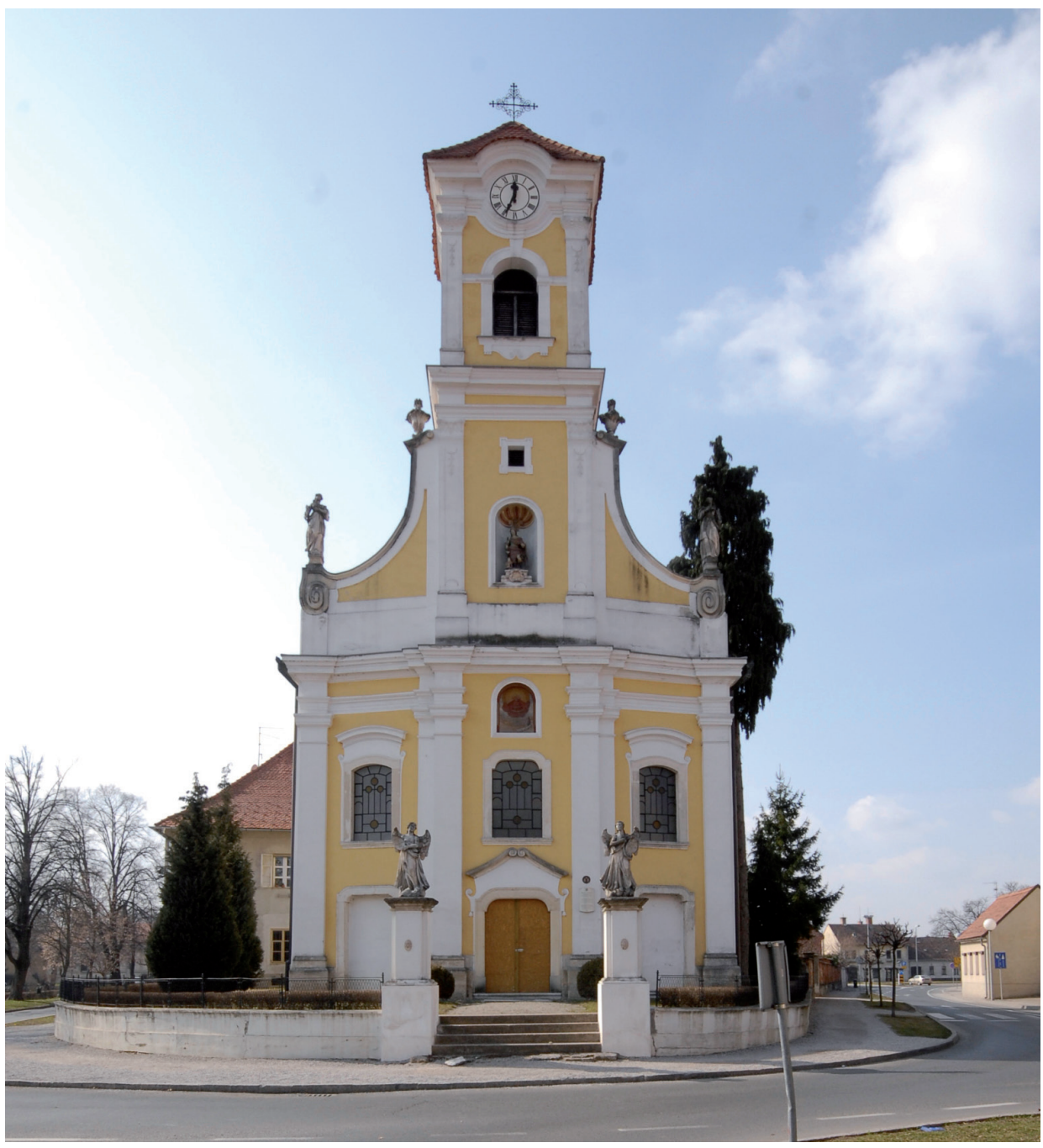

Slika 5. Glavno pročelje

Prema istraživanjima dr. Ivy Lentić Kugli autor projekta za obnovu glavnog, istočnog pročelja i tornja kapele je graditelj Johann Adam Poch; jedan njegov signirani, ali nažalost nedatirani projekt sačuvan u Državnom arhivu u Varaždinu upućuje na tu mogućnost. Prema tlocrtu, presjeku i nacrtu pročelja može se za- 
ključiti da se radi o kapeli Sv. Florijana, premda postoje stanovita odstupanja od projekta i izvedenog stanja. ${ }^{17}$

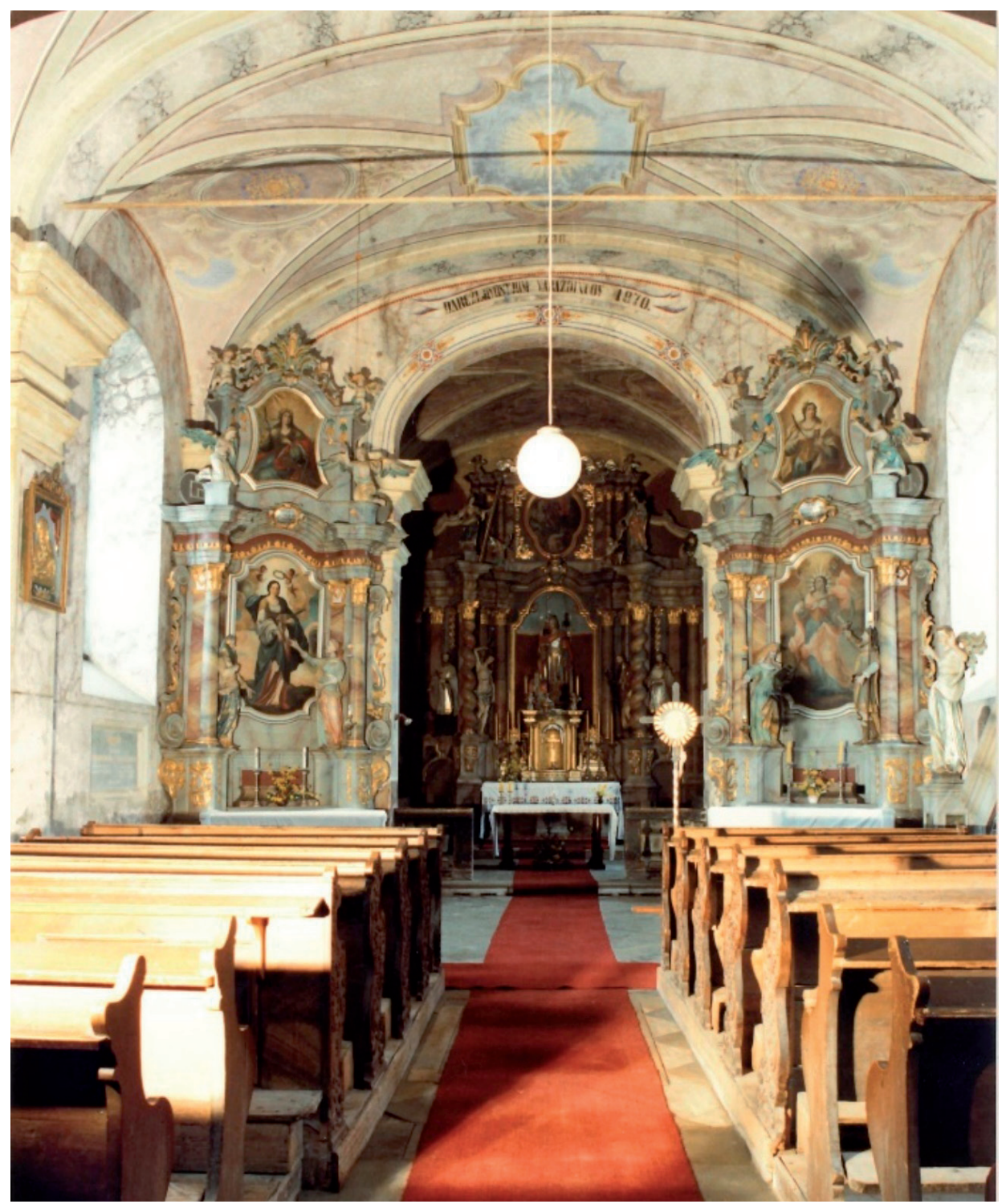

Slika 6. Unutrašnjost, pogled prema svetištu, zatečeno stanje




Početkom 19. st. u malom prostoru južno od ulaza, ispod pjevališta uređena je kapela Božjeg groba, prema natpisu u unutrašnjosti podignuta 1816. godine.

Godine 1870. u kapeli su izvođeni opsežni radovi: unutrašnjost je obnovIjena ličenjem zidova, oslikavanjem mramorizacije i ornamentalnih ukrasa te ponovnim oslikavanjem oltara, na način uobičajen u drugoj polovici 19. st. Zapis o toj velikoj obnovi bio je na trijumfalnom luku i glasio je: DARAŽLJIVOSTJUM VARAŽDINCOV 1870.

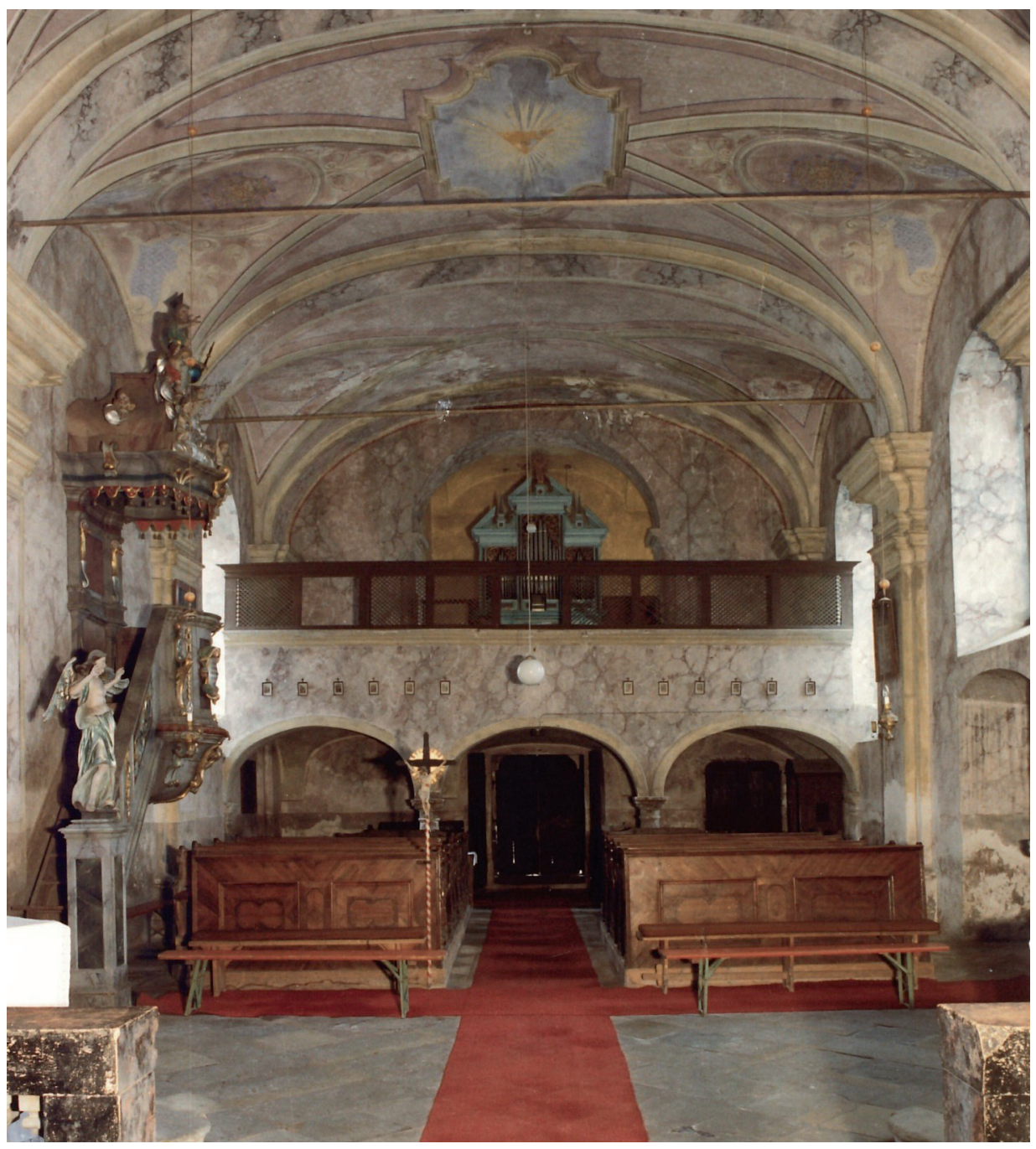

Slika 7. Unutrašnjost, pogled prema pjevalištu, zatečeno stanje 
Zatečeni oslik bio je rezultat obnove unutrašnjosti iz 1870. godine. Unutrašnje ziđe, pilastri i svodovi kapele sv. Florijana bili su oslikani sivkastim i sivoljubičastim tonovima mramorizacije.

Unutar manjih, ovalnih medaljona u susvodnicama bili su naslikani geometrijski, zrakasto simetrični ornamenti, a u većima složenijeg konkavno-konveksnog oblika motivi Božjeg oka i kaleža s hostijom.

Sondiranje bojenih slojeva na različitim dijelovima zida, svoda, pilastara i pjevališta otkrilo je bijeli jednolični vapneni nalič. Na gornjem dijelu trijumfalnog luka, neposredno uz liniju početka svoda, ispod natpisa koji svjedoči o velikoj obnovi unutrašnjosti 1870. godine, otkriven je natpis koji datira završetak gradnje u doba zrelog baroka. Slova su napisana crnom bojom na bijeloj podlozi, kapitalom baroknog tipa.

Prva dva para susvodnica ukrašena su medaljonima i štukaturom koja svojim motivima - akantusovim lišćem, viticama, trakama s kuglicama, ljuskama, zmajskim glavama, rešetkama s cvjetićima - predstavlja karakterističan rad četrdesetih godina 18. stoljeća. Stucco motivi skladno su komponirani unutar trokutastog oblika susvodnice, a dva po dva para nasuprotnih susvodnica imaju jednak dekorativni motiv. Štukatura je plitka, čvrsta i sigurnih obrisa, bijelo na bijeloj podlozi s ružičastim detaljima.

Sondiranje slikanih slojeva unutar medaljona dalo je izvanredne i iznenađujuće rezultate. U manjim ovalnim medaljonima otkriveni su detalji ženskih likova, svetih mučenica koje se stalno spominju uz glavnog patrona ove crkve. Sonde otvorene u većem medaljonu pokazivale su da se radi o grupi Presvetog Trojstva. Već i ove relativno male otkrivene površine odavale su vještinu izvedbe, sigurnost poteza, skladnu kolorističku shemu i smisao za kompoziciju.

Tema i prikaz Presvetog Trojstva srodni su slici na svodu sakristije bivše isusovačke crkve, sada katedrale Uznesenja BDM, koja je datirana i signirana; to je rad varaždinskog slikara Blaža Grubera iz 1727. godine i jedna je od najranijih iluzionističkih slika u Hrvatskoj. ${ }^{18}$ Tipologija svetica u ovalnim medaljonima pokazuje sličnosti s vremenski bliskom slikom Marije Immaculate iz kapele sv. Vida iz 1737. godine, koja je također pripisana Blažu Gruberu. ${ }^{19}$

Niz indicija govori u prilog njegovu autorstvu zidnih slika na svodu kapele. Četrdesetih godina 18. stoljeća, u doba urešenja novopodignute kapele, upravo je Blaž Gruber izvodio pozlatarske i polikromatorske radove na drvenom inven-

18 I. LENTIĆ KUGLI, „Blasius Gruber pictor varasdiensis“, VMKH, Zagreb, 1970., br. 1-2, 13.-20.

19 Isto kao bilj. 20, 17. 
$\operatorname{taru}^{20}$ i nije isključeno da je kao već iskušani slikar figuralnog i arhitektonskog iluzionizma bio angažiran i za oslikavanje svoda. Od 1751. do svoje smrti 1753. godine Gruber je bio jedan od starješina kapele sv. Florijana ${ }^{21}$, a u svojoj oporuci traži da bude u njoj i pokopan. ${ }^{22}$

Proučavajući varaždinsko slikarstvo 18. st. dr. Ivy Lentić Kugli ${ }^{23}$ zaključuje da je većina varaždinskih 'pictora' 18. stoljeća, izuzev Blaža Grubera iz prve polovice 18. stoljeća bila veoma skromnih slikarskih mogućnosti te bi i to govorilo u prilog njegovom autorstvu. Zidne slikarije s početka 19. stoljeća (1814. - 1816. godine) nalaze se u kapelici Božjeg groba, koja se nalazi s južne strane, ispod pjevališta. Nad ulazom u crkvu kronogram je ispisan crnim i crvenim slovima: SEPULCRUM JESU CHRISTI VERI DEI VERE ET GLORIOSE RESURGENTUS (GROB ISUSA KRISTA PRAVOGA BOGA ODISTA I SLAVNO USKRSNULOGA). Slikarije prikazuju vojnike, pozaspale čuvare Kristova groba, a na zidovima i svodu naslikani su bokori cvijeća i kartuše s natpisima, uokvirene asimetričnim rocailleima.

Postojeći drveni inventar kapele sv. Florijana s početka četrdesetih godina 18. st. bio je naručen i izrađen upravo za taj prostor. Među izvođačima koji su sudjelovali u opremanju kapele spominju se imena domaćih majstora. Prema zapažanjima dr. Ivy Lentić Kugli, bilo je uobičajeno da su izradu oltara kod varaždinskih majstora naručivale crkve i kapele kojima je grad Varaždin bio kolator, za razliku od redovničkih crkava za koje su oltari bili naručivani od stranih majstora. ${ }^{24}$

Kada je tridesetih godina 18 . st. srušena drvena kapela i započeto zidanje i uređenje nove, stari je drvorezbarski inventar uklonjen. Interesantno je, međutim, spomenuti podatke o tom inventaru 17. stoljeća koje nalazimo u protokolima kanonskih vizitacija posljednje četvrtine 17. st. Odmah se uočava da su i tadašnji oltari bili posvećeni istim svecima - sv. Florijanu, sv. Apoloniji i sv. Luciji, tj. svetim mučenicima iz prvih kršćanskih vremena i zaštitnicima od nesreća i bolesti kojima se pobožni puk utjecao moleći pomoć i zaštitu.

20 Isto kao bilj. 20, 18. Podaci iz Historijskog arhiva Varaždina (HAV), I-1, XLVIII-32.

21 Isto kao bilj 20, 19., podaci iz HAV, I-1, 1751-la-2769-H-1294.

22 Isto kao bilj 20, 19., podaci iz HAV, I-1, 7-K-16.

23 I. LENTIĆ KUGLI, „Prilozi za istraživanje varaždinskih 'pictora' u 18. stoljeću (I. dio)“, VMKH, Zagreb, 1969., br. 3, 3.-11.

24 I. LENTIĆ KUGLI, „Nekoliko podataka o varaždinskim kiparima 18. stoljeća“, VMKH, Zagreb, 1969., br. $4,7$. 
U najranijim zapisima o bočnim oltarima iz 1675., 1678. i 1683. godine ${ }^{25} \mathrm{uz}$ kratki je opis naznačeno da se nalaze u portiku, drvenom trijemu ispred pročelja kapele. Propovjedaonica iz tog vremena također je u trijemu, drvena je i prenosiva. Glavni je oltar lijep drvorezbarski rad, obojen crnom bojom, djelimice pozlaćen, sa slikom sv. Florijana naslikanom na platnu, koja se nalazi u sredini retabla. Protokoli vizitacija iz 1688., 1694. i 1695. godine s još više pojedinosti opisuju inventar kapele. ${ }^{26}$

Stari oltar sv. Florijana bio je dvokatni retabl, crno obojen i obilno pozlaćen; sredinu je resila slika sveca zaštitnika naslikana na platnu, a s bočnih su strana bili kipovi sv. Josipa i sv. Joakima. U drugom je katu bio kip Božanske Majke, a sa strana dva anđela adoranta.

Oltar sv. Lucije, smješten u trijemu, uz središnji kip svetice imao je oslikane ploče s likovima sv. Katarine i sv. Barbare, što navodi na zaključak da se radilo o jednokatnom krilnom retablu. Oltar sv. Apolonije, također postavljen u trijem, u sredini je imao sliku svetice, a sa strana kipove sv. Ivana ev. i sv. Marije Magdalene; u gornjem je dijelu kip B. D. Marije. Svi su kipovi bili djelimice pozlaćeni i oslikani bijelo, imitirajući bijeli polirani mramor.

25 Protokoli...: knj.161/II, 1675.p.119: “... altare 1 ... in atrio altaria 2 ...”

Knj. 162/III 1678, 48: “ ...De altaribus: Altare in Capella habet 1 S. Floriani opera arculario bene elaboratum cum certu statuis colore nigro tinctum et in certis partibus inauratum, cum imagine $S$. Floriani in medio in tela depicta...Ante fores ubi Porticus habent altaria 2, ad Cornu Evangelij S. Luciae $V$. et $M$. bene elaboratum cum certus statuis depictis et in partibus inauratis ...ad Cornu vero Epplae S. Apoloniae cum eius imagine it tela depicta..."

- knj. 163/IV,1683..43 r. "...habent in eodem atrio dua altaria murata cum suis tabulis depictis et statuis bene ornatis, unum est S. Apoloniae aliud S. Luciae, in eodem atrio habet Cathedra lignea, transferibilis....Altare in Capella est unum sub titulo S. Floriani muratum non consecratum cum una tabula et plurimus nigro colore depicta, statuis item deauratis..."

26 Protokoli... 164/V 1688., 56-57: " ...in Capella est altare unum muratum non consecratum Tituli S. Floriani quod ornat in medio Imagine S. Floriani in tela picta, ex partibus ad cornu Evan. Statua sculpta deaurata S.Josephi nutrcii Xti, ad cornu Epplae statua sculpta deaurata S. Joachimi. In superiori parte in medio statua sculpta Magnea Matris deaurata,ex partibus vero 2 Angelorum sculpti et deaurati. Columnis, tabelis et cifris operis arcularij et sculptorij nigro colore depicti, crucifixus supra Ara habet, candelabra ad suis candelis 4 variis coloribus depicti... antipendium in tela picta... item in Porticu habet unum Altare muratum non consecratum Tituli S. Luciae Virg et Mart quod ornat statua sculpta S. Luciae deaurata et in media colorata. Ex partibus ad Cornu Evang. Imago S. Catharinae Virg. Et Mart. In tabula picta, ad Cornu Epplae Imago S. Barbarae Virg. Et Mart. similiter in tabula picta... columnis et cifris operis arcularij et sculptorij depicti et in partibus deaurati... in eodem porticu habet aliud altare muratum non consecratum, ad Cornu Epplae, tituli S. Apoloniae Virg. et Mart. quod ornat in media Imagine S. Apoloniae in tela picta. Ex partibus ad Cornu Evang. Statua S. Joanni Apli et Evang. albo colore decolorata ad instar albi marmoris, ad Cornu Epplae Statua S.Mariae Magd. Sculpta et similiter depicta. In superiori parte statua sculpra Magnae Matris similiter depicta et in partibus deaurata ... ornat suis columnis, tabelis et cifris arcularij et sculptorij operis variis coloribus depicti et deaurati ..." 
Vizitacije iz sredine i druge polovice 18. st, koje bi zbog usporedbe sa zatečenim stanjem postojećeg inventara bile vrlo interesantne, opisuju, nažalost, malo detalja. Spominju patrocinije, navode da su oltari novi, pozlaćeni i oslikani, opremljeni svime potrebnim za obavljanje Službe Božje. U više je navrata uočen lijepi sakristijski ormar od orahovog drveta. ${ }^{27}$

Već ranije spomenuti majstor Mathias Saurer prema sačuvanim je ugovorima autor rezbarenog i pozlaćenog tabernakula na glavnom oltaru ${ }^{28}$, a komparativnom analizom moglo bi mu se pripisati i autorstvo arhitektonskih i ornamentalnih elemenata oltara Sv. Florijana. Figuralna bi se plastika, pak, prema istraživanjima dr. Doris Baričević, mogla povezati s kiparom Ivanom Adamom Rosenbergerom i njegovim utjecajem. ${ }^{29}$ Taj je majstor, središnja ličnost varaždinskog kiparskog kruga, ostavio velik opus izveden u drvu u Varaždinu i okolici, a vrlo često u suradnji upravo sa stolarom Mathiasom Saurerom. Karakteristike njegova stila „(...) oštro su i precizno rezane crte lica, uska ramena i slojevito preklopljeni nabori nad koljenom istaknute noge. Preko glavnih oltara u kapelama sv. Vida (1752. g.) i sv. Florijana (1740. g.) u Varaždinu (...) raširio se taj tip svetačkog lika u mnogim varijantama (...) po mnogim crkvama u širokom okružju Varaždina."

Dva niza crkvenih klupa smještenih u lađi, vrlo vrijedan dio inventara kapele sv. Florijana, drugi su arhivski potvrđen rad majstora Saurera, koji ih je izradio za svotu od 80 guldena i završio 1745 . godine. ${ }^{30}$ Klupe su izrađene od masivne orahovine; bočne stranice ukrašene su rezbarijama s motivima rešetke, vitica, akantusovih listova i girlandi obrnutih čaški, karakterističnim za četrdesete godine 18. st., dok su čeone i začelne stranice ukrašene ukladama i geometrijskom intarzijom izvedenom u orahovom furniru.

27 Protokoli... : knj. 169/X, 1748., 18.-19.; knj. 169/X, 1752., 57.; knj. 169/X, 1755, 81.." ... visitavi Capellam Sancti Floriani Martyris ... hoc capella habet altaria tria eleganter facta et depicta suis omnibus sacrificio Missae neccesarius proviso ... suis armaribus pro conservandis calicibus ex asseribus nuceis arcularij operis bene adaptatis exornat."

28 I. LENTIĆ KUGLI, isto, 11., podaci iz HAV I-1, LXXXI-52.

29 Doris BARIČEVIĆ, Kiparstvo manirizma i baroka, Katalog izložbe "Sveti trag”, Zagreb, 1994., 312.

30 I. LENTIĆ KUGLI, “Crkvene klupe varaždinskog stolara Matije Saurera”, VMKH, Zagreb, 1971., br. 2, 5.-10. 




Slika 8. Klupe u lađi, zatečeno stanje

Uz ime M. Saurera treba svakako navesti i veliki sakristijski ormar koji je 1742. g. izradio za sakristiju kapele sv. Florijana, koji se danas nalazi u kapeli sv. Lovre u Starom gradu Varaždinu. Taj ormar spominje, osim već citiranih vizitatora iz 1755. i 1771. g. i Gjuro Szabo napominjući da je „, ... lijepo nu obično barokno posuđe smješteno u sakristiji u vrlo lijepom, nu žalibože zapuštenom ormaru, urešenom s intarzijama. " ${ }^{31}$

Drugi poimence spomenuti majstor - slikar i pozlatar Blaž Gruber prema sačuvanom je ugovoru od 1743. do 1745. g. izvodio pozlatarske i polikromatorske radove na propovjedaonici. ${ }^{32}$ Sondiranjem slojeva na arhitektonskim dijelovima propovjedaonice ustanovljeno je da je ispod naknadne sivkaste mramorizacije sačuvana izvorna, Gruberova koloristička shema - mramorizacije u crvenkastim, ružičastim, svijetlomodrim, zelenkastim i sivoljubičastim tonovima te pozlata i posrebrenje s lazurama.

31 Gjuro SZABO : Spomenici grada Varaždina, rukopis, g. 1919.p. 47.

32 I. LENTIĆ KUGLI, “Blasius Gruber pictor varasdiensis" VMKH, 1970, 18., podaci iz HAV I-1,XLVIII-33 i XLVIII-33. 




Slika 9. Restauratorska sonda na bazi kipa sv. Ivana Nepomuka na glavnom oltaru, vidljiv izvorni oslik

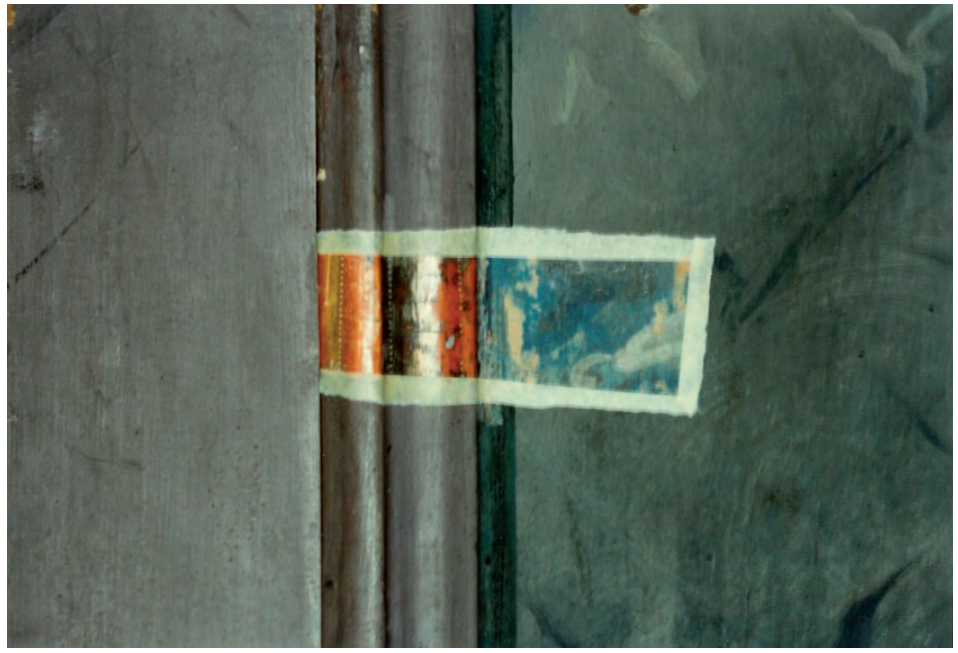

Slika 10. Restauratorska sonda na predeli na glavnom oltaru, vidljiva izvorna mramorizacija, puncirano posrebrenje i pozlata

Ostaje otvoreno pitanje da li je Gruber autor istovrsnih polikromatorsko slikarskih radova na glavnom i bočnim oltarima. 
Valja istaknuti da je spominjanje slikara - polikromatora koji surađuju s drvorezbarskim radionicama, a pogotovo takav arhivski dokumentirani podatak, u našoj povijesti umjetnosti vrlo rijetko, pa je sačuvani dokument tim više važan i interesantan. Prema istraživanjima dr. Doris Baričević kipovi s bočnih oltara sv. Lucije i sv. Apolonije rad su Ivana Pittnera. ${ }^{33}$

\section{GRAĐEVINSKO - OBRTNIČKI I KONZERVATORSKO - RESTAURATORSKI RADOVI}

Hrvatski restauratorski zavod, tada još Restauratorski zavod Hrvatske, ${ }^{34}$ započeo je radove na obnovi kapele 1992. godine, na poziv tadašnjeg Zavoda za zaštitu spomenika kulture u Varaždinu, danas Konzervatorskog odjela u Varaždinu u sastavu Uprave za zaštitu kulturne baštine Ministarstva kulture Republike Hrvatske. Izvedena je konstruktivna sanacija crkve ${ }^{35}$ u razini krovnog vijenca izvedbom armirano-betonskog serklaža te sustavom unakrsno postavljenih čeličnih zatega $^{36}$, a potom je, oslanjajući se na arhivska istraživanja dr. Ivy Lentić Kugli i arhitektonske snimke postojećeg stanja, ${ }^{37}$ provedeno konzervatorsko-restauratorsko istraživanje i snimanje detalja glavnog pročelja. ${ }^{38}$ Rezultati istraživanja prikazani su u izvještaju te se ovdje iznose u sažetom obliku. ${ }^{39}$ Otvorene su sonde kroz slojeve boje i žbuke na pročeljima te je pregledan zvonik s kojega je mjestimice otpala stara žbuka sa štukaterskim detaljima, kao i ostatak nekadašnjeg južnog pročelja svetišta neposredno ispod krovnog vijenca koji je dogradnjom Xenodochia zatvoren u prostor potkrovlja.

33 D. BARIČEVIĆ, Kiparstvo manirizma i baroka, Katalog izložbe „Sveti trag“, Zagreb, 1994., 301.-340.

34 Hrvatski restauratorski zavod osnovan je uredbom Vlade RH od 19. prosinca 1996. godine (NN 2/97), spajanjem Zavoda za restauriranje umjetnina (osnovanog 1948. g.) i Restauratorskog zavoda Hrvatske (osnovanog 1966. g.).

35 Ukupno je široka 11,5 m, a dugačka $29 \mathrm{~m}$.

36 Projekt sanacije izradila je Katarina BENCE, d.i.g., RZH.

37 Zdravko PTIČEK, d. i. a., Crkva sv. Florijana, Snimak postojećeg stanja, VING poduzetnički inženjering, 1991/92 Varaždin.

38 Tim je vodio Zvonimir Matica, d. i. a., a činili su ga još: Silvije Novak, prof. pov. umj., Josip Minks, akad. slikar, Nesto Orčić, akad. kipar i Teodora Kučinac, d. i. a.

39 Silvije NOVAK“ Izvještaj o konzervatorskim istraživanjima crkve sv. Florijana u Varaždinu“, Hrvatski restauratorski zavod, Zagreb, 1993., 1.-11., 15 fotografija. 


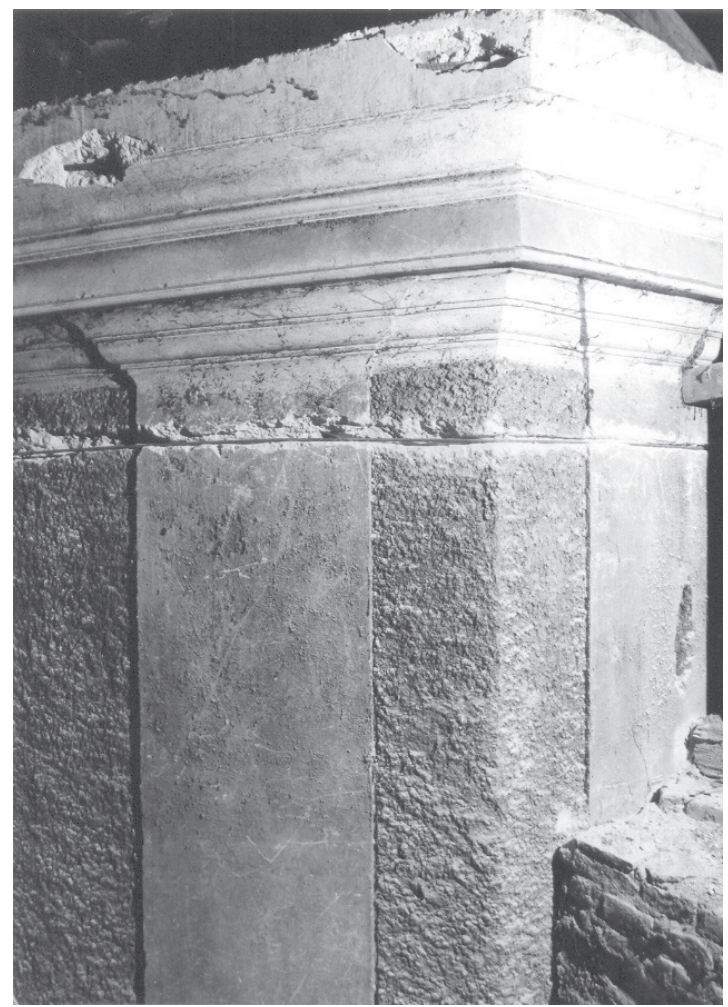

Slika 11. Detalj prvotne fasade na zidu svetišta u potkrovlju

Analizom istraženih detalja na dijelovima pročelja koja pripadaju izgradnji kapele u razdoblju od 1733. do 1738. g s onima na današnjem glavnom pročelju čija je gradnja započela 1777., može se pratiti razvoj varaždinske arhitekture u 18. stoljeću. Pročelja starijeg dijela kapele ožbukana su špricanom „rustičnom“ žbukom tamnosive boje, a kao kontrast toj hrapavoj površini i tamnoj boji isticali su se pažljivo zaglađeni bijeli pilastri koji raščlanjuju pročelja na pravilna polja. ${ }^{40}$ Kapiteli pilastara oblikovani su obratima bogato profiliranog krovnog vijenca. Okviri otvora s polukružnim nadvojima na starijem dijelu kapele su kameni, s naglašenim impostima i trostruko stupnjevanim zaglavnim kamenjem. O izgledu prvotnog glavnog pročelja može se samo nagađati jer je uklonjeno nakon požara 1776. godine. Sonda na južnom pročelju pokazala je da je potkrovni vijenac prelazio s bočnog na nekadašnje glavno pročelje kapele. Zacijelo je označio pod-

40 Usp. župnu crkvu sv. Nikole u Varaždinu. 
nožje zabata, a pretpostavljamo da je glavno pročelje također bilo raščlanjeno pilastrima. U ulaznom prostoru vidi se profilirani kameni okvir portala, nekadašnjeg glavnog, a danas vjetrobranskog ulaza.

Godine 1777. formirano je novo glavno pročelje s raskinutim zabatom iz kojega izranja zvonik. Stražnji zid novoga zvonika oslanja se na ostatke nekadašnjeg pročelja. Gruba žbuka korištena je samo na produljenim zidovima lađe da bi se sakrio spoj novog i starog dijela kapele. Na južnom produljenom zidu bila je sunčana ura, sačuvana samo u osnovnom obliku. Novo glavno pročelje izvedeno je zaglađenom žbukom na kojoj se ističu pažljivo izvedeni klesarski, kiparski, štukaterski, slikarski i stolarski detalji koji svjedoče o visokoj razini umjetničkog obrta u Varaždinu neposredno nakon požara. U Povijesnom arhivu Varaždina sačuvan je nacrt Joannesa Adama Pocha, vrlo sličan glavnom pročelju kapele sv. Florijana. Nad zvonikom je prikazana lukovica koja bi bolje pristajala ovoj crkvi nego sadašnji niski šatorasti krović. Neki detalji su vremenom izmijenjeni, primjerice niša s lažnim vratima iza kojih je spiralno stubište, te lijeva vrata, nekad otvorena, iza kojih je početkom 19. st. uređena kapelica Božjeg groba.

Nakon konzervatorsko-restauratorskih istraživanja izrađen je projekt uređenja pročelja. ${ }^{41}$ Predložena je obnova prema zatečenom stanju, gotovo nepromijenjenom u odnosu na vrijeme izgradnje zvonika krajem 18. stoljeća. Radovi su izvedeni 1995. godine. Uklonjena je trošna žbuka do zidane podloge. Pročelje je žbukano produžnom žbukom, površinske obrade istovjetne zatečenoj i obojeno prema kolorističkoj shemi iz faze izgradnje zidanog tornja. ${ }^{42}$ Nadopunjeni su štuko ukrasi (kapiteli lezena, lambrekini, spiralne uške) ${ }^{43}$, a slikani ${ }^{44}$ i skulpturalni ${ }^{45}$ ukrasi su konzervirani i restaurirani. Na zabatima su zamijenjene kamene poklopnice i volute. Sunčani je sat na južnome pročelju rekonstruiran. ${ }^{46}$

41 Z. MATICA, T. KUČINAC, Glavni i izvedbeni projekt građevno-statičke sanacije i obnove pročelja crkve, RZH, 1993.

42 Građevinsko-obrtničke radove je izvodilo poduzeće Zagorje-Građenje iz Varaždina (voditelj građenja: Vlasta Ivaniš), a operativni nadzor je obavljala tvrtka Finalgradnja (Anđelko Perši, d.i.g.).

43 Radove na štuku izveo je Stjepan Jerković, akad. kipar.

44 Slikarske restauratorske radove izveli su akad. slikari: Miro Usenik, Ivan Štimac, Josip Minks.

45 Radove na kamenoj plastici izveli su: Kamenko Klofutar, Mijo Jerković, Roko Domić, akad. kipar, Božo Martinčević.

46 I. LENTIĆ KUGLI, Građa za proučavanje varaždinskih 'pictora' u 18. stoljeću (II. dio), 36.-48.: Josephus Amon je 1780. oslikao brojčanike na crkvenom tornju kod sv. Florijana, a moguće i brojčanik sunčanoga sata na južnome zidu crkve. Zlatko BRITVIĆ, Sunčane ure, Astronomsko društvo „Oton Kučera“, Zagreb, 1983. (ljubaznošću Gustava Krena, Zvjezdarnica Zagreb). Projekt: Teodora Kučinac, izvedba: Josip Minks. 


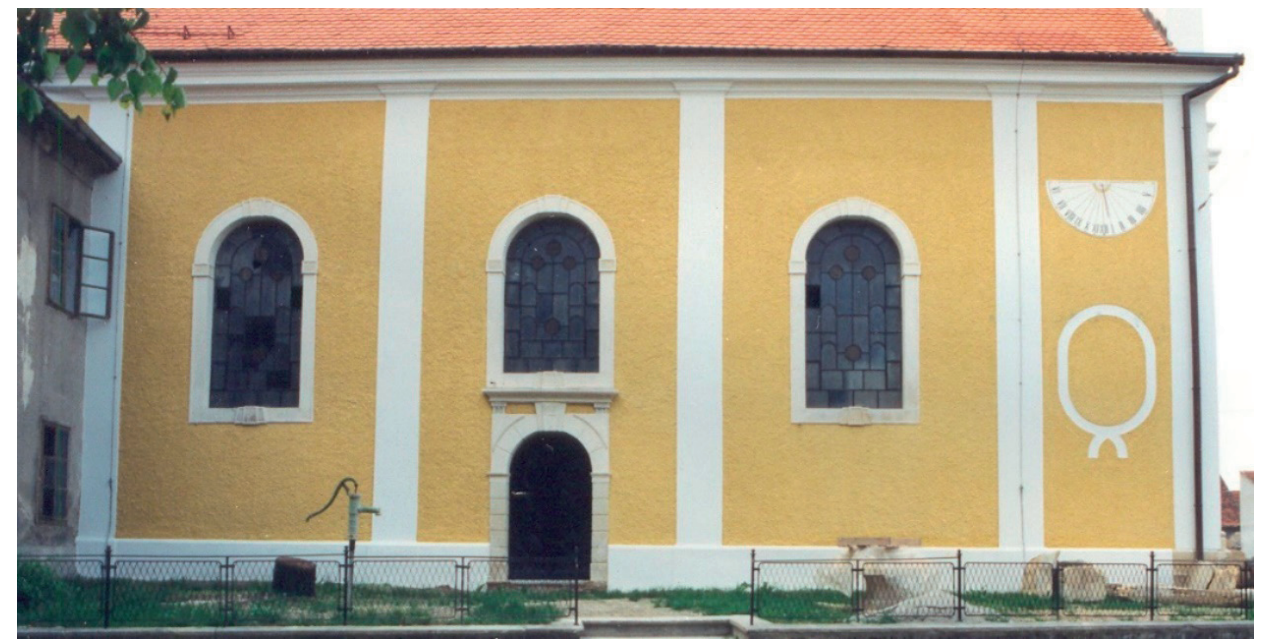

Slika 12. Južno pročelje lađe nakon radova

Konzervatorsko-restauratorsko istraživanje unutrašnjosti, zidnog oslika i drvenog inventara obavljeno je u jesen 1997. godine ${ }^{47}$, a rezultati su prikazani u konzervatorsko-restauratorskom elaboratu istraživanja i prijedlogu obnove unutrašnjosti. ${ }^{48}$ Nakon valorizacije slikane dekoracije predloženo je da se sa zidova, svodova i sa drvenog inventara uklone zagasiti preslici iz 1870. g. te da se restaurira i obnovi izvorni, barokni oslik iz 1738. godine kojemu su poznati autori.

Zaštitni, građevinsko-obrtnički ${ }^{49}$ i konzervatorsko-restauratorski radovi izvodili su se postupno, dugi niz godina, u skladu s financijskim i operativnim mogućnostima, od 2001. do 2017. godine. Sredstva za radove osiguravalo je Ministarstvo kulture RH uz sudjelovanje Grada Varaždina u inicijalnoj fazi radova. Crkva je devet godina bila zatvorena (2005. - 2014.).

Veliki problem crkve bila je izražena vlaga na podu i donjim zonama zidova, uobičajena pojava u starim građevinama. Polaganje zidova direktno na temelj omogućuje neometano kapilarno dizanje vlage iz tla, migraciju i kristalizaciju

47 Istraživačke radove je financirao Grad Varaždin. Istraživanje i snimanje detalja obavila je ekipa Hrvatskoga restauratorskog zavoda u sastavu: Edita Usenik, Ana Pohl, Vesna Šimičić, Edo Anušić, Iva Bartolić, Snježana Hodak, Danuta Misiuda, Kamenko Klofutar, Mijo Jerković, Jasna Bartoniček, Alma Orčić-Vukašin, Teodora Kučinac kao voditelj programa, Dragica Krstić, Hrvoje Malinar, Jasenka Vuković, Jurica Škudar te vanjski suradnici: Siniša Čular i Krunoslav Tišljar.

48 Danuta MISIUDA, Edita USENIK, Vesna ŠIMIČIĆ, Teodora KUČINAC, Hrvoje MALINAR, dr.sc. Felicita BRIŠKI, Danijela IVANKOVIĆ, Dragica KRSTIĆ, dr. sc. Mira PETROVIĆ, Jasenka VUKOVIĆ, Konzervatorsko-restauratorski elaborat istraživanja i prijedlog obnove, HRZ, Zagreb, svibanj 1998.

49 Građevinsko-obrtničke radove na crkvi izvodila je tvrtka Euro-line d.o.o. iz Ludbrega, vl. Slavko Blagaj. 
građevinskih soli na površini zida i poda prilikom pada relativne vlage u zraku te, posljedično, degradaciju površine - žbuke ili kamena. Uzorci vapnene žbuke, uzeti s raznih mjesta u crkvi na visini $20-170 \mathrm{~cm}$ od poda, sadržavali su visoke koncentracije klorida, sulfata i nitrata..$^{50}$ Obavljena je i kvalitativna mikrobiološka analiza. Na podu, u zidu i na klupama pronađene su mješovite kulture bakterija i plijesni. ${ }^{51}$ Primijećeno je rošenje dijelova poda u vrijeme promjene s hladnog na toplo razdoblje; neki dijelovi poda bi zbog kondenzacije i prisutnosti higroskopnih soli bili posve mokri, a drugi suhi pa su obavljena dva niza mjerenja temperatura poda - jedan u zimskom razdoblju, a jedan u proljeće.

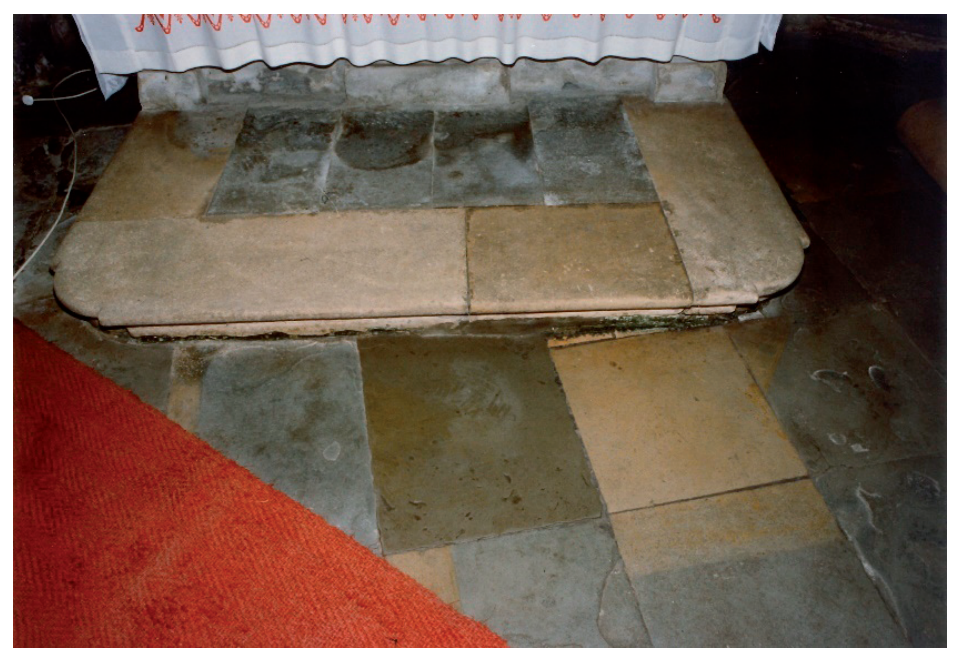

Slika 13. Detalj poda i oltarne stube u lađi, rošenje pojedinih ploča, zatečeno stanje

Prikaz distribucije topline izolinijama potvrdio je različitu toplinsku vodljivost, a time i gustoću podloge. ${ }^{52}$ Kasnija arheološka istraživanja potvrdila su pretpostavku o postojanju šupljina - kripti ispod poda.

50 Danijela IVANKOVIĆ, Dragica KRSTIĆ, Laboratorijsko izvješće, Hrvatski restauratorski zavod, 14. 3. 1998.

51 Dr. sc. Felicita BRIŠKI, „Laboratorijski izvještaj“, Sveučilište u Zagrebu, Fakultet kemijskog inženjerstva i tehnologije; Konzervatorsko-restauratorski elaborat istraživanja i prijedlog obnove, HRZ, Zagreb, svibanj 1998. „... rezultati analize ukazuju da u uzorcima D1, D2 i E prevladavaju bakterije iz roda Bacillus, Acctinomyces i Streptomyces, dok u uzorku F samo bakterije iz roda Bacillus. Također je u svim uzorcima prevladavala mješovota kultura plijesni i to najčešće različite vrste iz roda Penicillium, dok je kod uzorka D2 bila prisutna samo vrsta Penicillium patulum. Nadalje u uzorku F ustanovljena je prisutnost plijesni iz roda Sporothrix, koja se može pojaviti na drvenom materijalu."

52 Hrvoje MALINAR, „Prethodno izvješće o mjerenjima temperature poda u crkvi sv. Florijana u Varaždinu“, Konzervatorsko-restauratorski elaborat istraživanja i prijedlog obnove HRZ, Zagreb, svibanj 1998. 
Pri planiranju sanacije tražio se način da se proces kolebanja vlage uspori, a šteta smanji. Premda je crkva zidana na uzdignutom platou, izvedena je drenaža oko nje te odvodnja krovnih voda, ${ }^{53}$ ne bi li se smanjio dotok površinske i procjedne vode do temelja i zidova. Oko svetišta je podignuta ograda kako bi se spriječilo odlaganje otpada uz zidove. U unutrašnjosti je uklonjena vlagom i isoljavanjem oštećena žbuka u podnožju zidova, do visine $2 \mathrm{~m}$ od tla. $U$ toj zoni je nanesena lagana, vrlo porozna vapnena žrtvena žbuka za prihvat viška soli. Ta je žbuka nakon nekoliko godina uklonjena i zamijenjena 'trajnom' žbukom. Planirana je kompletna zamjena podložnih slojeva poda kako bi se povećala toplinska izoliranost poda od zemlje kao toplinskog spremnika. Podno i podžbukno grijanje, kojim bi se održavala ujednačena temperatura, tj. smanjilo zimsko ohlađivanje poda i donjih zona zidova te spriječila kondenzacija, odbačeno je zbog procijenjenih teškoća u održavanju režima grijanja i održavanju sustava. Predviđeni su slijedeći slojevi poda: deblji sloj frakcije krupnog šljunka položen na podlogu, potom tanji sloj sitnog šljunka, sloj ekspandirane gline i sloj vapnenog estriha. Prisutnost većih i manjih šupljina smanjuje kapilaritet i pridonosi smanjenju toplinske provodljivosti podloge. Ovaj koncept primjenjivan je kasnije i na drugim objektima.

Veliko pitanje bilo je kako postupiti s trošnim kamenim opločenjem koje je zbog zamjene podložnih slojeva valjalo demontirati. Kamene ploče (lapor s nejasno izraženom stratifikacijom i klastični sitnozrnati pješčenjak) ${ }^{54}$ različitih dimenzija (primjerice: 2 × 2 polja, 1 × 3 polja, 1 polje) postavljene su u urednom dijagonalnom rasteru u svetištu $(31 \times 31 \mathrm{~cm})$ i prednjim i izloženim dijelovima crkvenoga broda $(47,5$ x 47,5 cm), dok su u stražnjem, ulaznom dijelu korištene pravokutne ploče raznih dimenzija u slobodnijoj ortogonalnoj postavi.

53 Radove je prema Izvedbenom projektu br. 2-088/98 iz 1998. godine i dopuni projekta iz 2001. godine koje je izradio Geoexpert PROJEKT d.o.o. (Božidar MAGDALENIĆ d.i.g. i suradnici, Elaborat za izvedbu radova za zaštitu temelja i poda kapele od djelovanja površinske i podzemne vode) izvodila tvrtka Zagorje Tehnobeton d.d. iz Varaždina u razdoblju od 15. listopada 2001. do 20. kolovoza 2002. godine. Tijekom iskopa radove je nadzirao arheolog iz Gradskog muzeja Varaždin (osim oko svetišta), a obavljeno je i zaštitno arheološko istraživanje sa sjeverne strane lađe. Nalazište je geodetski snimio Zavod za fotogrametriju, a o istraživanjima je GMV sastavio Izvještaj 7. siječnja 2002. godine.

Spoj oborinskih i procjednih voda na glavnu kanalizacijsku mrežu izvelo je poduzeće Varkom iz Varaždina u sklopu uređenja prometne mreže oko kapele tijekom ljeta 2002.

Tvrtka GIM d.o.o. izradila je geodetsku snimku izvedenog stanja 22. kolovoza 2002. godine.

Stručni nadzor je obavljao Hrvatski restauratorski zavod (Izvješće nadzornog inženjera, 16. 12. 2002.) u suradnji s Geoexpert PROJEKTOM d.o.o. koji je obavljao projektantski nadzor (Izvješće projektanta o izvedenim radovima na zaštiti temelja od djelovanja podzemne vlage br. Ri-2-088/98-1/2002.)

54 „Izvještaj o ispitivanju mineraloško - petrografskog sastava uzoraka 6768 i 6769“, Mineraloško-petrografski zavod PMF-a, Zagreb, 25. 10. 2002. 
DANUTA MISIUDA, TEODORA KUČINAC: Crkva sv. Florijana u Varaždinu. Rezultati ...

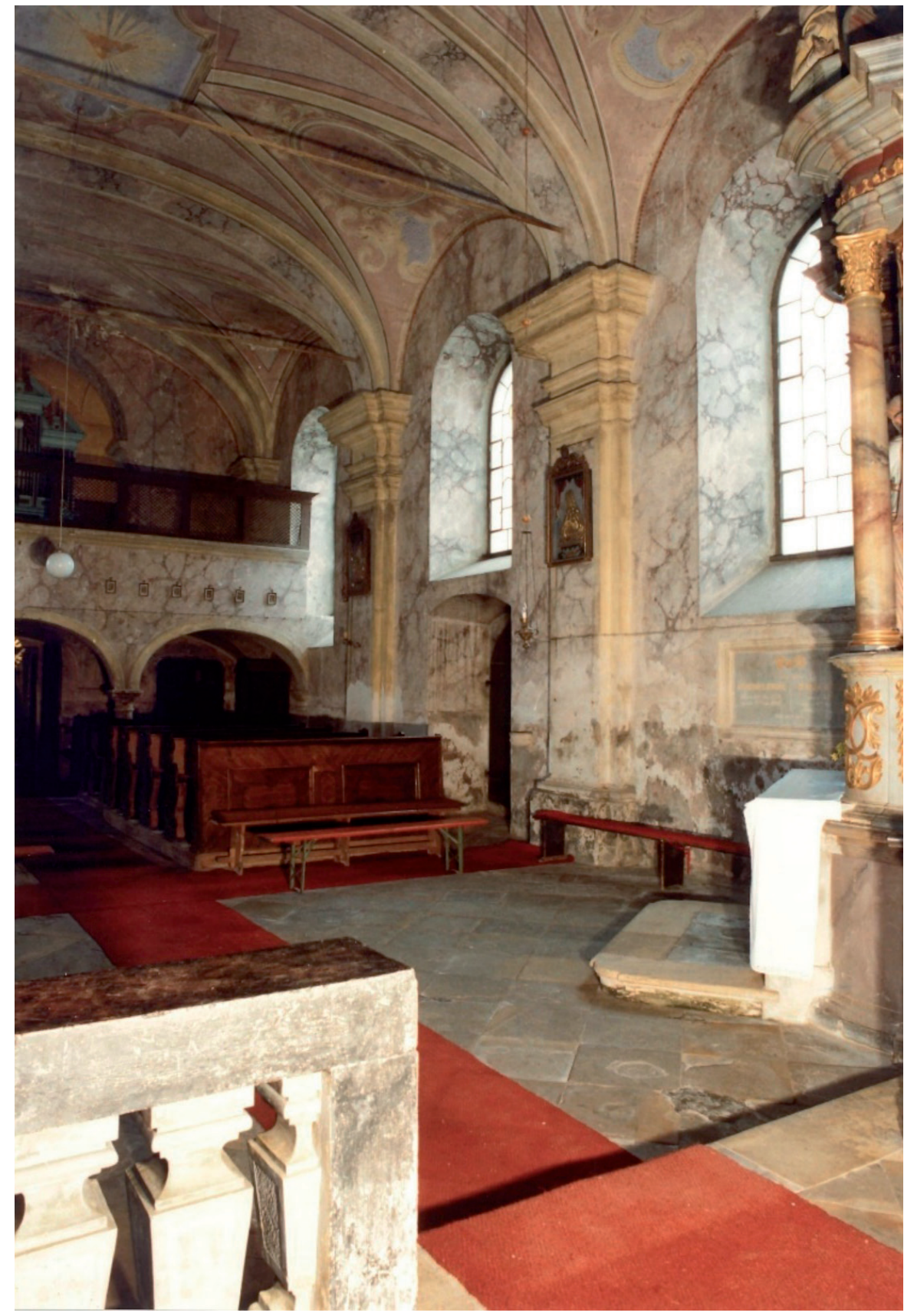

Slika 14. Unutrašnjost, pogled na južni dio crkve, zatečeno stanje 


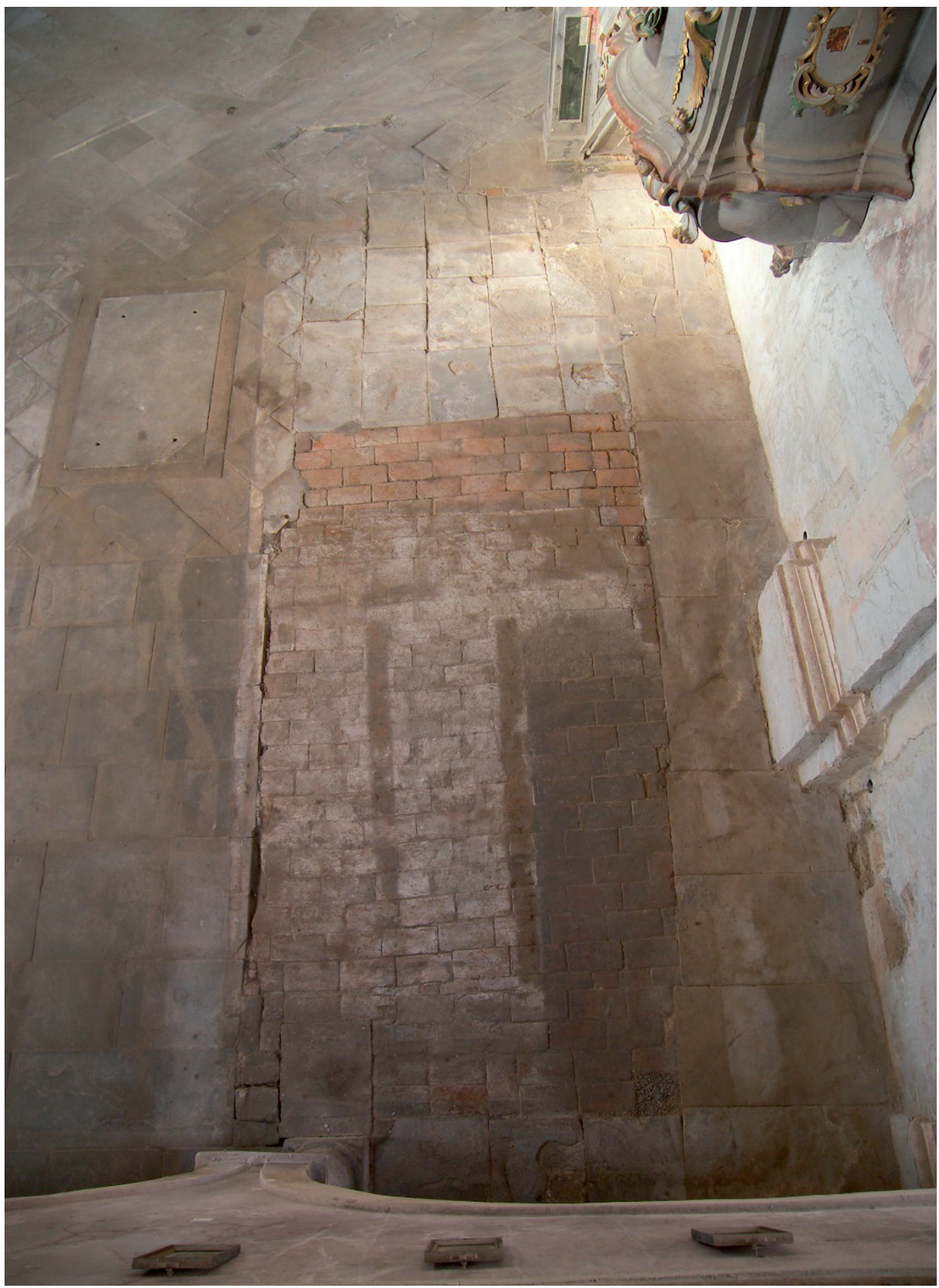

Slika 15. Detalj poda nakon uklanjanja sjevernog reda klupa u lađi 
Pod je ispod klupa bio popločan opekom. Kamen se na mnogim mjestima ljuskao pa je površina poda bila neravna. Hodna ploha vremenom je kalcificirala, dok je donja, položena na zemljanu podlogu ostala mekana te se lako mogla zagrebati. Prvotni plan je bio sačuvati što više originalnih ploča, a oštećene zamijeniti novima. Potraga za odgovarajućim zamjenskim kamenom nije davala zadovoljavajuća rješenja. Kamenolomi iz kojih je dobavljan kamen za opločenje, ne samo crkve sv. Florijana već i mnogih drugih crkava i građevina u širokoj okolici, iscrpljeni su i nama nisu više poznati. Konačno smo odabrali talijanski kamen iz Vicenze. ${ }^{55}$ Riječ je o krupnozrnatom pješčenjaku, strukturom i bojom donekle sličnom jednoj vrsti kamena koja je korištena u crkvi.

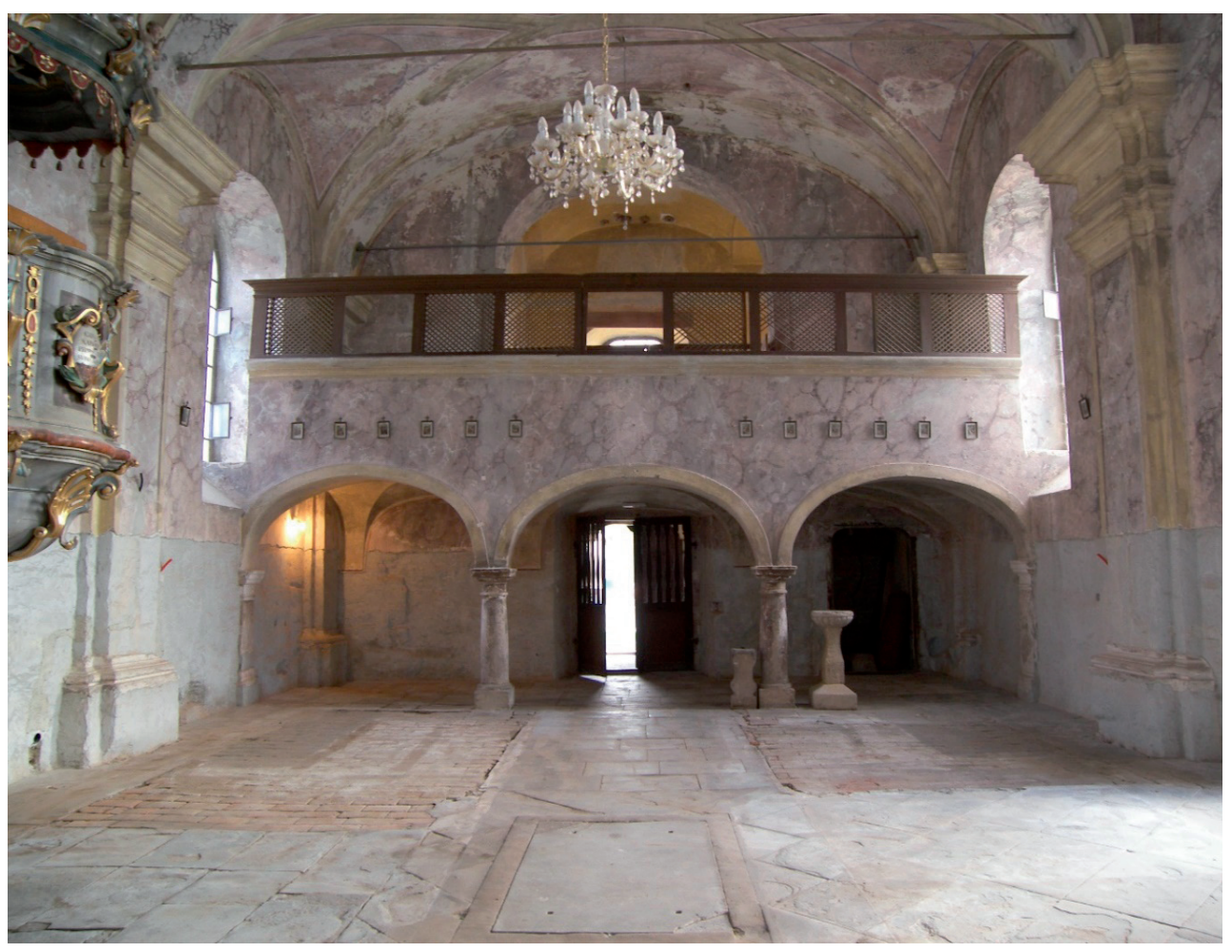

Slika 16. Unutrašnjost, pogled prema pjevalištu nakon uklanjanja inventara

55 Dobavljač Klesarstvo Nestić iz Gornjeg Dragonošca. Analiza fizikalnih karakteristika postojećega, izvornog kamena, dala je nešto bolji rezultat od analize novoga kamena, vjerojatno zbog procesa dulje izloženosti zraku i kalcifikacije u površinskom sloju. 
Kod demontaže, manipulacije i sušenja zatečenih podnih ploča dolazilo je do njihovog daljnjeg raslojavanja i pucanja. Ploče su podvrgnute isoljavanju u kišnici. Sačuvana i upotrebljiva količina, nažalost, nije bila dovoljna da se njome popuni veći dio poda svetišta i kapele pa je tim pločama na kraju popločen samo ulazni prostor i kapelica Božjeg groba. ${ }^{56} \mathrm{Na}$ kraju su u svetištu i lađi u cijelosti postavljene nove podne ploče od kamena tipa Pietra Leccese, piljene na debljinu od $6 \mathrm{~cm}$, u dijagonalnom rasteru prema izvornoj postavi.

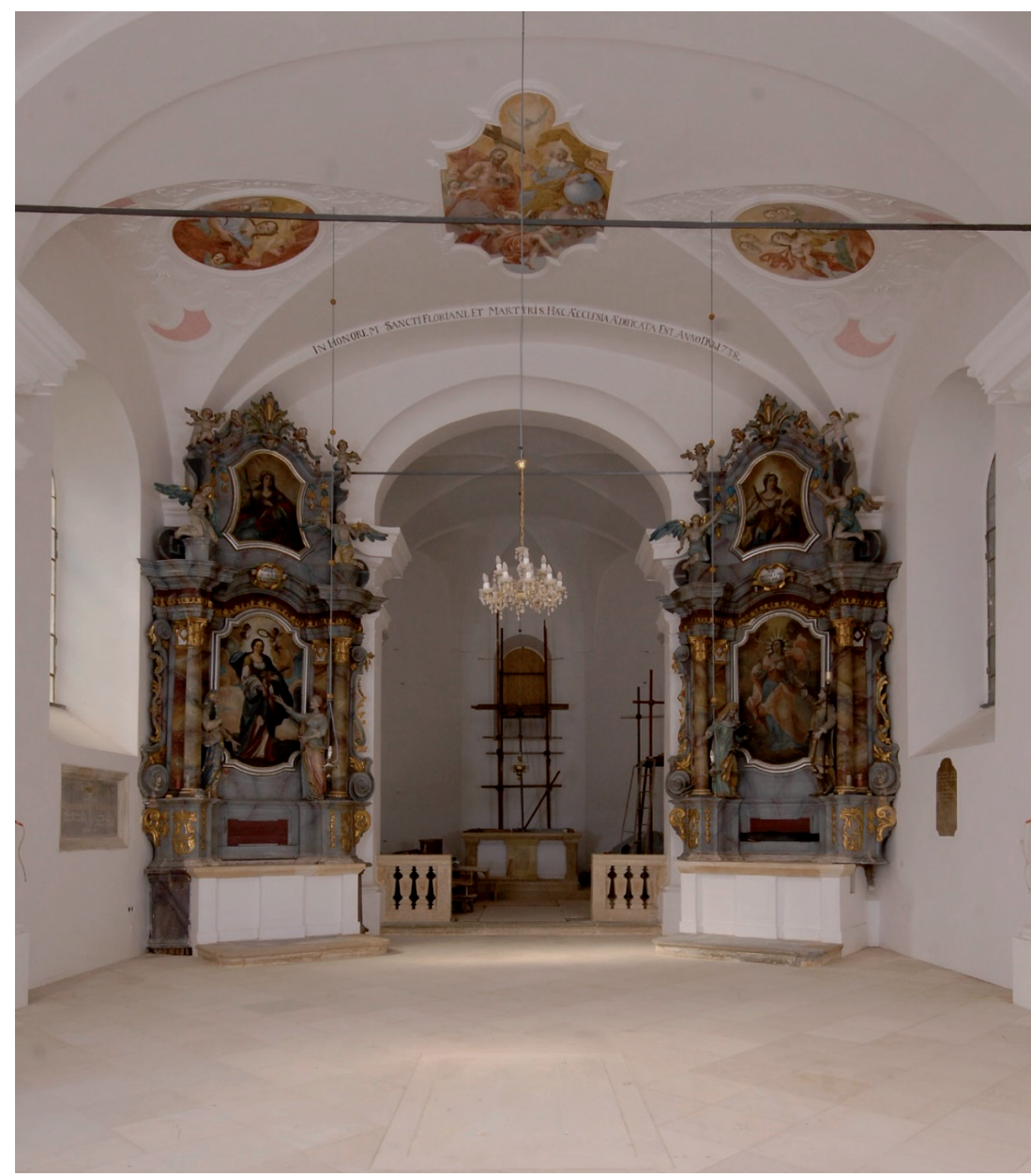

Slika 17. Unutrašnjost, pogled prema svetištu nakon postavljanja novog poda

56 Ostatak je upotrijebljen u manjoj crkvi sv. Marije u Rukljevini blizu Varaždinskih Toplica. 
Zaštitni radovi u unutrašnjosti počeli su obnovom dviju prostorija sakristije. Uklonjeno je staro kameno opločenje poda, sanirani su temelji, izveden je sustav njihovog prozračivanja te je izvedeno novo opločenje poda slično zatečenom. ${ }^{57}$ Zamijenjeni su prozori te žbuka na zidovima i svodu.

Radovi su nastavljeni u svetištu. Planirano je da se oslik iz posljednje velike obnove 1870. g. potpuno ukloni s prva dva svodna polja uz trijumfalni luk u lađi, gdje bi se otkrila štukatura i medaljoni s figuralnim oslicima iz prve faze, a da se preslik na ostalim površinama prebijeli. Stoga je u svetištu napravljena fotodokumentacija zatečenog stanja, katalog tipičnih oštećenja, pregled sondi, grafička dokumentacija zatečenog oslika te su obavljene probe čišćenja i učvršćivanja pigmentnoga sloja. ${ }^{58}$

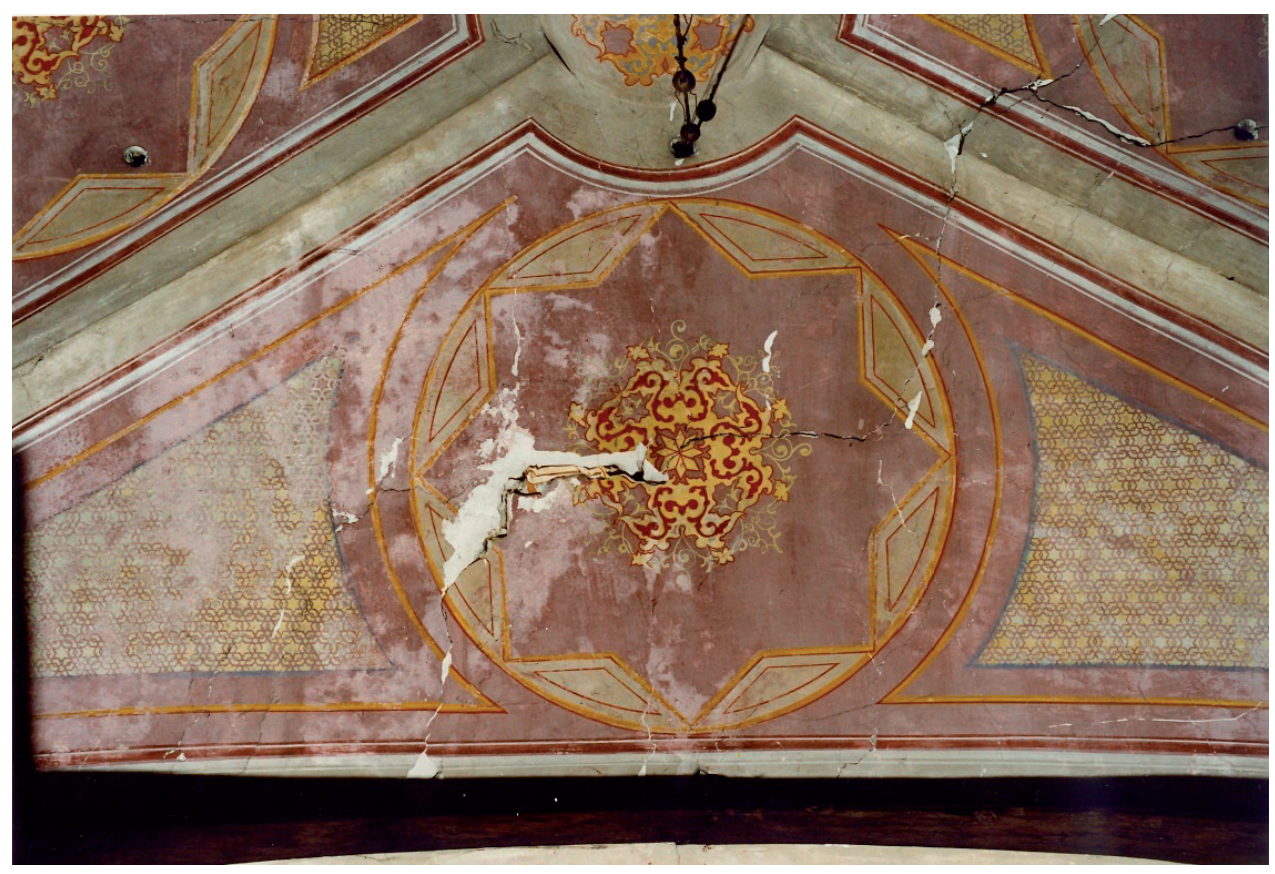

Slika 18. Detalj svoda u svetištu, zatečeno stanje

57 Arheološki nadzor u unutrašnjosti obavljao je $H R Z$, Odjel za kopnenu arheologiju - sakristija: Luka Bekić, svetište: dr. sc. Ana Azinović, istraživanje u lađi: dr. sc. Tajana Pleše, Dalibor Kereša, Josip Čimin.

58 Ivan SRŠA, Veronika ŠULIĆ, Izvještaj o stanju bojenog sloja na svodu i zidovima svetišta, o njegovu učvršćivanju i probama čišćenja, HRZ, Zagreb, 2005. 
Veće pukotine na zidovima i na svodu sanirane su povezivanjem odvojenih zidnih masa unakrsno postavljenim štapnim sidrima i injektiranjem. ${ }^{59}$ Zidovi i svod su oprani kalijevim sapunom te prebijeljeni vapnom. Na poleđini trijumfalnog luka zadržan je manji dio preslika, koji je također prebijeljen.

Koncept cjelovite prezentacije skladne barokne unutrašnjosti izmijenjen je kada je, nakon reorganizacije Hrvatskog restauratorskog zavoda, unutar Službe za pokretnu baštinu zaključeno da se uklanjanje preslika s kućišta orgulja, oltara i propovjedaonice te restauriranje izvornog oslika ne uvrsti u program restauratorskih radova i to zbog nedostatnih kapaciteta Odjela za polikromiranu drvenu plastiku, nepoznatog postotka očuvanosti izvornoga slikanog sloja te zbog relativno dobrog postojećeg stanja navedenog inventara u odnosu na predmete koji su se tada obrađivali u okviru programske djelatnosti HRZ-a. Kako je već navedeno, prema arhivskim izvorima koje su potvrdile istraživačke sonde i komparativne analize, slikane dekoracije - medaljone na svodu izveo je Blaž Gruber. Otkrivanje izvornoga oslika na drvenom inventaru upotpunilo bi i proširilo poznavanje opusa toga kvalitetnog varaždinskog majstora - umjetnika iz druge polovice 18. stoljeća.

U redovni su program uvršteni konzervatorsko- restauratorski radovi na glavnome oltaru sv. Florijana. S obzirom na kompleksnost i sveobuhvatnost građevinskih radova, krenulo se u njegovu djelomičnu demontažu. Sredinom 2005. godine demontirane su sve skulpture i cjelokupna zona atike. Naknadnim pregledima donje zone oltara ustanovljeno je potonuće prizemnih dijelova desne strane ophoda, zbog truljenja drveta, što je dovelo do narušavanja statike oltara. Stoga je trebalo demontirati sve dijelove glavnog oltara i deponirati ih u prostorije tadašnjeg Restauratorskog centra Ludbreg. Za vrijeme građevinskih radova, u razdoblju od 2007. do 2011. godine obavljeni su konzervatorsko-restauratorski radovi na skulpturama, dok je na najugroženijim dijelovima oltara izvršena stolarska sanacija nakon koje su obavljeni konzervatorsko-restauratorski radovi čišćenja, konsolidacije natapanjem, rekonstrukcije kredne osnove te završnog retuša i pozlate saniranih dijelova oltara ${ }^{60}$. Kako je glavni oltar vremenom pretrpio značajnije preinake, ovom se prilikom išlo sigurnijim putem, tako da je konzerviran i restauriran preslik s kraja 19. stoljeća. Stara zidana menza koja se nagnula pod teretom drvene konstrukcije srušena je te je po uzoru na nju sazidana nova.

59 Projekt sanacije pukotina zidova i svoda svetišta i trijumfalnog luka, elaborat br. R-42-3/2005, Geoexpert Projekt d.o.o., Zagreb, 2005.

$60 H R Z$, Odjel za polikromiranu drvenu skulpturu, Stolarska radionica, Restauratorski odjel Ludbreg; voditelj radova: Edo Anušić, radovi: Veljko Bartol, Stanko Kirić, Davor Bešvir, Roko Cypryn Buljan, Antonio Horvatić, Jelena Spevec, Sandra Planko, Tomislav Jakopaš, Željko Belić, Miriam Mrnjec. 
Rad na arhitektonskim elementima, zidnim slikama, štukaturi i ostalom inventaru nastavljen je zacrtanim smjerom. Nakon provedene fumigacije drvenog inventara ${ }^{61}$, crkva je ispražnjena, uklonjene su klupe te su provedena zaštitna arheološka istraživanja ${ }^{62}$ kojima su potvrđeni zidani temelji starije, pravilno orijentirane drvene kapele.

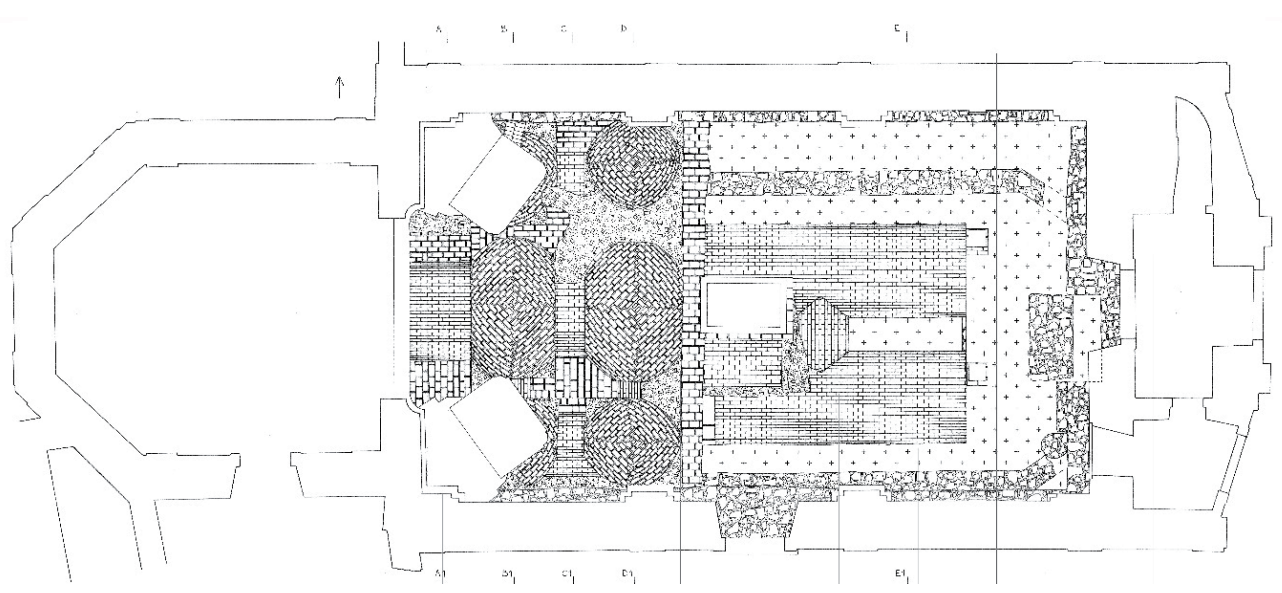

Slika 19. Nacrt pronađenih građevinskih struktura u lađi nakon arheoloških istraživanja

Širina temeljnih zidova je 55-60 cm, dok je širina unutrašnjeg prostora drvene kapele $640 \mathrm{~cm}$. Sačuvana duljina kapele iznosi $895 \mathrm{~cm}$. U prostoru poligonalne apside sačuvan je temelj oltara. Južni zid starije crkve proteže se neposredno uz južni temelj, dok je sjeverni zid položen paralelno sa sjevernim zidom današnje crkve i od njega udaljen 100 - 110 cm. Zapadni kraj starije crkve nije pronađen jer su na tom mjestu izgrađene kripte. Nakon iskopavanja vidjeli su se svodovi kripti: starije, u koju se ulazi kroz otvor u podu na sredini crkvenoge lađe te novije kripte koju je 1773. gradio majstor Jakov Erber. Starija kripta ima dvije izduljene komore nadsvođene bačvastim svodovima. Novija kripta ima kupolaste svodove - 6 polja u lađi i 3 u svetištu. Ulaz joj je bio na sjevernoj strani kapele, u zoni temelja, a naznačen je malim kamenim raspelom uzidanim iznad sokla. Taj je ulaz otkriven prilikom iskopa temelja radi izvedbe drenaže 2001. godine. ${ }^{63}$ Kripte su odijeljene zidom položenim u smjeru sjever - jug, nešto zapadnije od današnjeg južnog ulaza.

\footnotetext{
61 Agrosan d.o.o. iz Zagreba, vl. Vladimir Bertović.

62 Tajana PLEŠE, „Varaždin - kapela sv. Florijana“, Hrvatski arheološki godišnjak, 4 (2008), 165-167.

63 Arheološki nadzor je obavljala arheologinja Marina Šimek iz Gradskog muzeja Varaždin.
} 
Sanirani su svodovi pronađenih kripti, a potom je umjesto uklonjene zemlje nasipan krupni pa sitni šljunak te sloj ekspandirane gline da se smanji toplinska tromost poda, a time i kondenzacija na prelasku iz hladnoga u toplo razdoblje. $U$ podu je izveden novi razvod elektroinstalacija. ${ }^{64}$ Izveden je vapneni estrih kao podloga novom popločenju. Kamene ploče su položene u dijagonalnom rasteru na cijeloj površini svetišta i lađe. Uz manje popravke, nepromijenjeni su ostali kameni pod na pjevalištu, oltarna stuba, kao i podesti ispred bočnih oltara.

Osim opsežnih restauratorskih radova na slikanim medaljonima na svodu lađe 2008. - 2011. godine, ${ }^{65}$ provedeni su i konzervatorsko-restauratorski radovi na relativno dobro očuvanoj plitkoj finoj štukaturi koja ukrašava susvodnice. ${ }^{66}$ Plohe zidova i svodova bez slikanih i štukaterskih ukrasa očišćene su i prebijeljene.

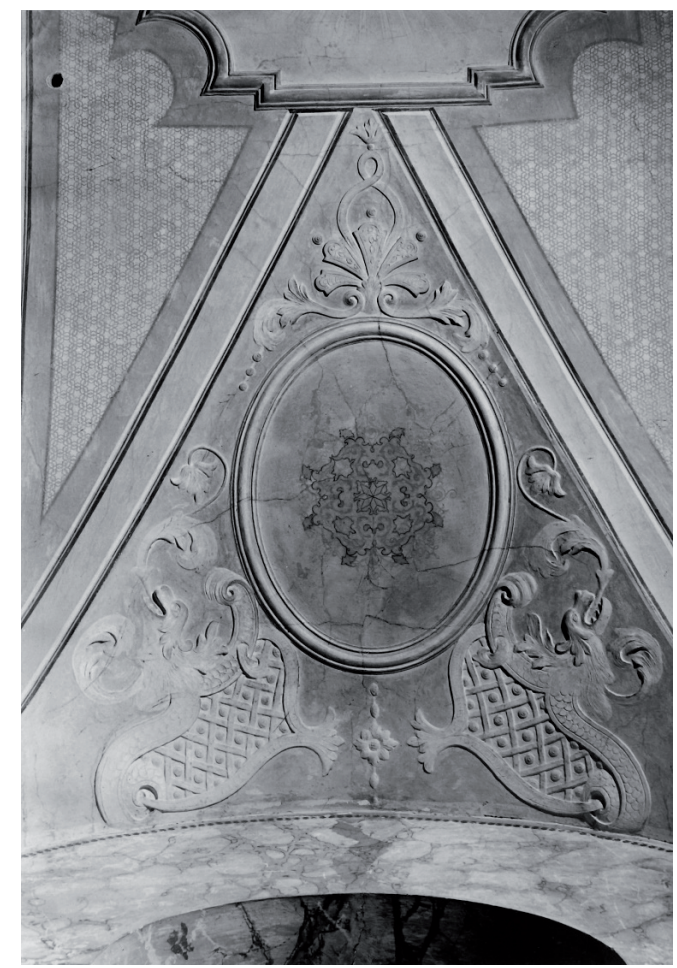

Slika 20. Detalj susvodnice na svodu u lađi s medaljonom i štukaturom, zatečeno stanje

64 Projekt: INARI d.o.o. iz Zagreba.

$65 H R Z$, Odjel za zidno slikarstvo i mozaik, voditeljica radova: Ivana Drmić, vanjska suradnica: Kristina Matković.

$66 H R Z$, Odjel za štuko, voditelj radova: Ante Čulo, vanjska suradnica: Lejla Koščević. 


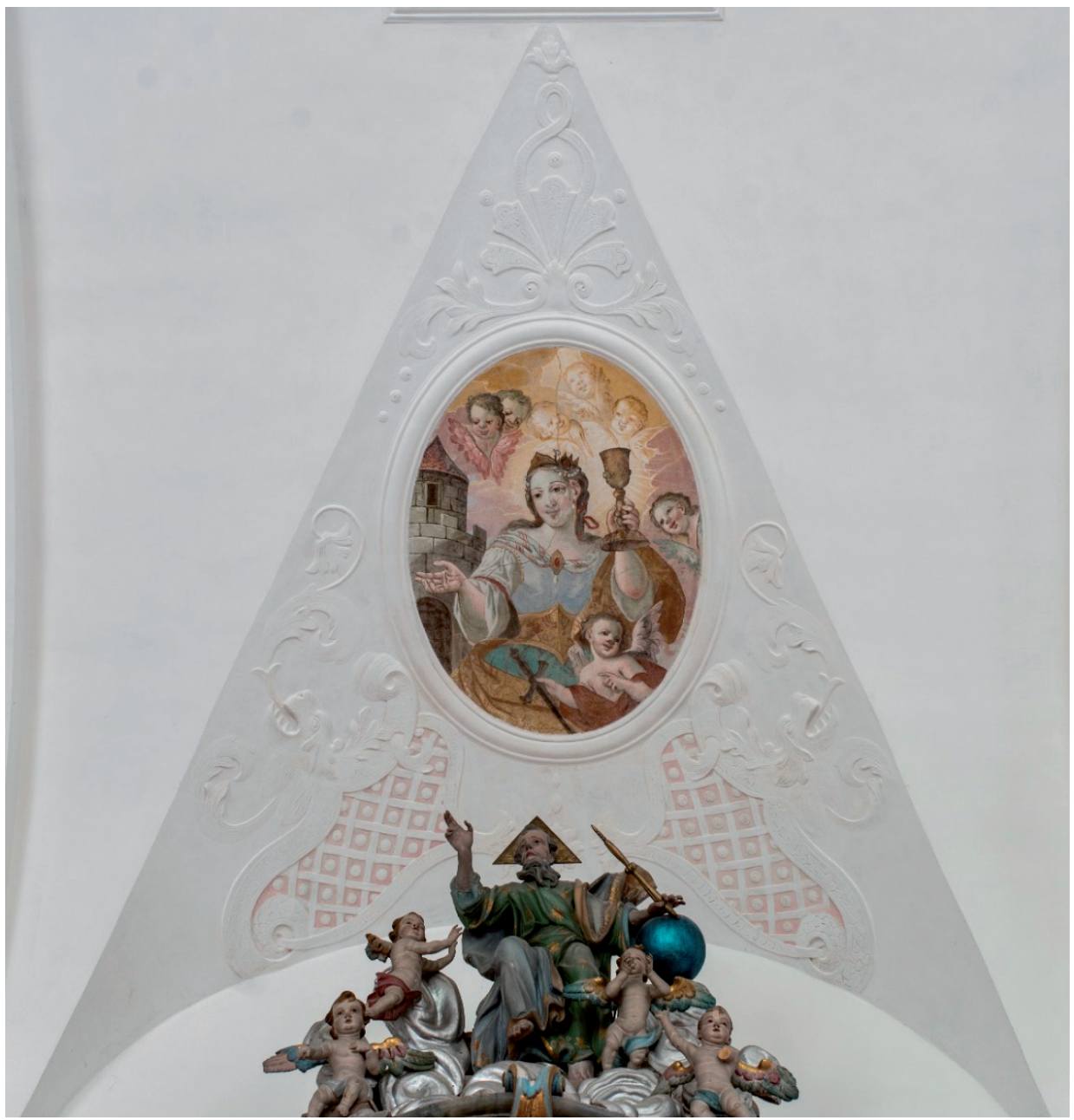

Slika 21. Detalj susvodnice na svodu u lađi s medaljonom i štukaturom nakon radova

Konzervatorsko-restauratorski radovi obavljeni su i na lijepim rezbarenim i intarziranim baroknim klupama u lađi. ${ }^{67}$ Drvena konstrukcija klupa i podest bili su izrazito crvotočni i pljesnivi. Rezbarije na bočnim stranicama, u manjoj mjeri napadnute crvotočinom, imale su niz mehaničkih oštećenja. Na čeonim i začelnoj plohi intarzija je bila crvotočna, a furnir se odvajao od nosioca ili je sasvim

$67 H R Z$, Odjel za polikromiranu drvenu plastiku, radna ekipa: Ksenija Šestek Ručević i Ivan Bujan, vanjska suradnica: Ida Gnjatović. 
nedostajao. Izvorna politura bila je oštećena i izblijedjela, a cijela površina prašnjava i isušena. Na gornjoj profilaciji bilo je vidljivo mnogo nagorenih mjesta i udubina od mehaničkih oštećenja. Sjevernom nizu klupa nedostajala je začelna ploha s rezbarenim stranicama. Obavljeno je površinsko čišćenje te preventivno podljepljivanje odignutih dijelova intarzije, umetanje nedostajućih dijelova furnira, rekonstrukcija oštećenih dijelova rezbarenih bočnih stranica, zapunjavanje mjesta oštećenih crvotočinom i drugih manjih oštećenja. Uklade su demontirane te su stolarski sanirane pukotine na konstruktivnim dijelovima. Rekonstruirani su nedostajući dijelovi intarzije i profiliranih letvica, a nakon kitanja manjih oštećenja i pripreme površine, uklada je lakirana. Obavljen je retuš i priprema podloge za šelakiranje. Podest, sjedalo, klecalo i polica izrađeni su nanovo u stolarskoj radionici ${ }^{68}$ te spojeni s restauriranim stranicama.

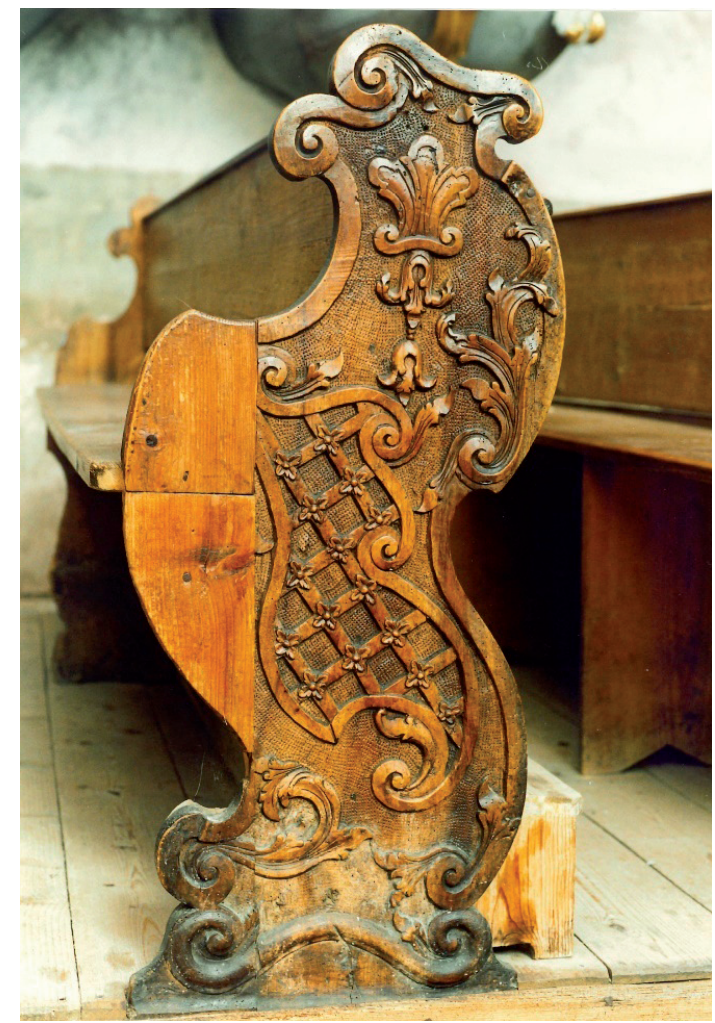

Slika 22. Bočna stranica klupe u lađi, zatečeno stanje

68 Radove je izvela Stolarija Kranjčec iz Ludbrega. 
DANUTA MISIUDA, TEODORA KUČINAC: Crkva sv. Florijana u Varaždinu. Rezultati ...



Slika 23. Niz sjevernih klupa u lađi nakon radova

Oštećena rešetkasta drvena ograda s posmičnim dijelovima na koru zamijenjena je novom, izrađenom prema originalu. ${ }^{69}$

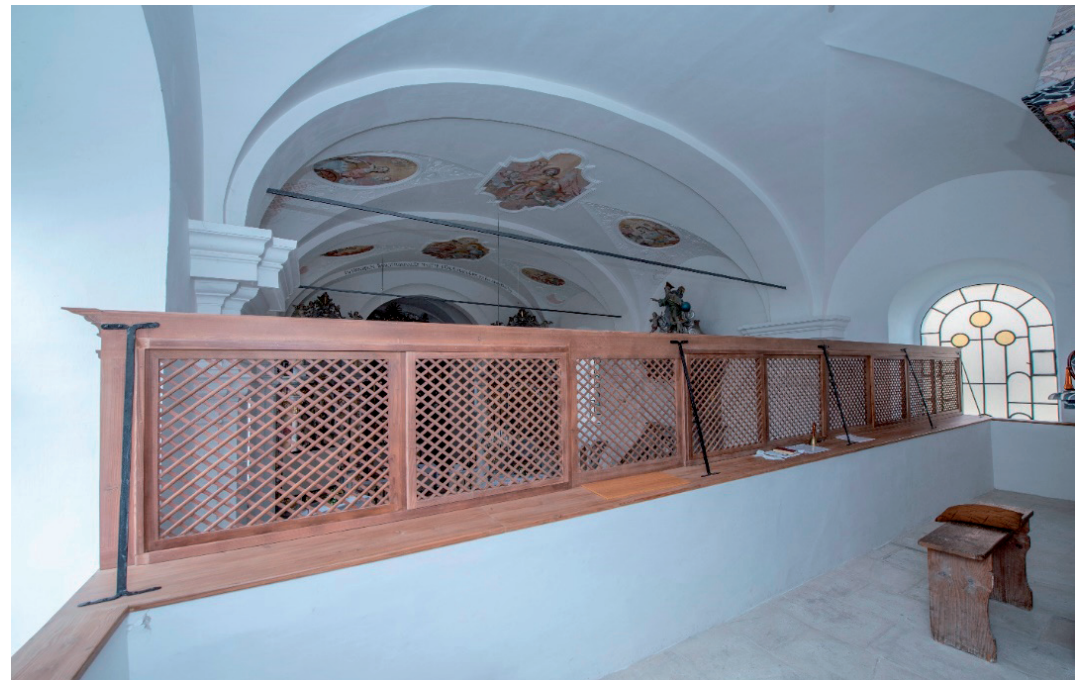

Slika 24. Nova rešetkasta ograda na pjevalištu

69 Radove je izveo Drvostil - Interijeri, vl. Damir Gizdavec iz Struge. 
Konzervatorsko-restauratorskom postupku u radionici HRZ-a podvrgnuta su lijepa ulazna drvena uklađena dvokrilna vrata ${ }^{70}$, kao i vratnice u svetištu prema sakristiji. ${ }^{71}$

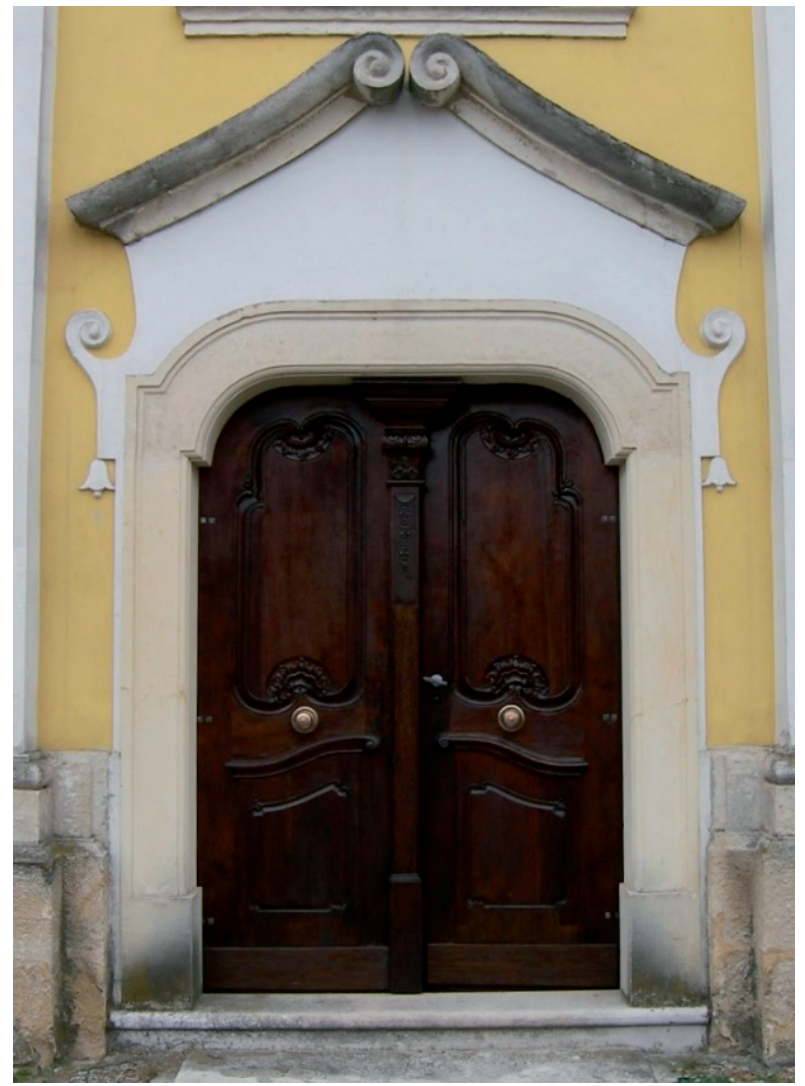

Slika 25. Glavni ulaz na istočnom pročelju nakon radova

$70 \quad H R Z$, Odjel za polikromiranu drvenu plastiku, Ivan Bujan.

71 Mirko Gnjatović, vanjski suradnik HRZ-a. 


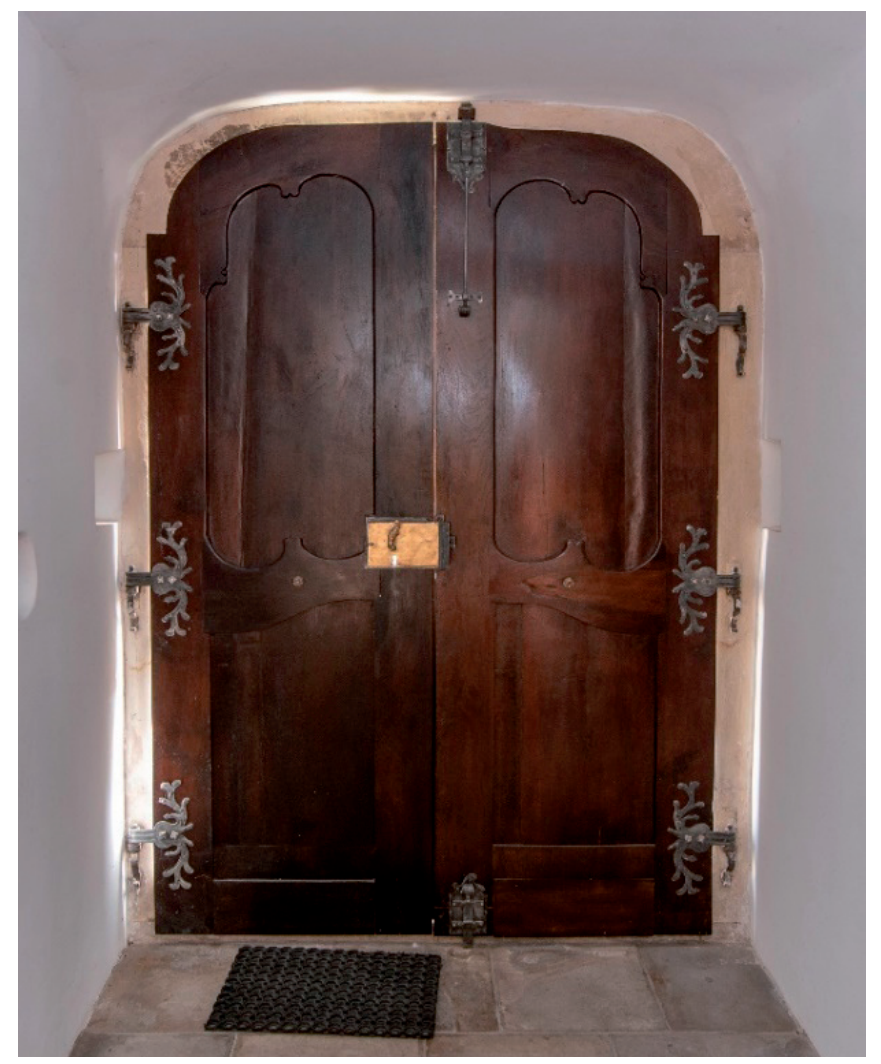

Slika 26. Vratnice glavnoga ulaza s unutarnje strane nakon radova

Premda se razmišljalo o projektiranju i izradi drvenih prozora na svetištu, odlučeno je da se ipak obnove postojeći metalni prozori, koji datiraju iz druge faze uređenja crkve. Metalna konstrukcija je očišćena i zaštićena, a mozaik stakla zamijenjena. Na okanca koja se mogu otvarati radi zračenja prostora postavljene su mrežice kako bi se spriječio ulazak ptica. 


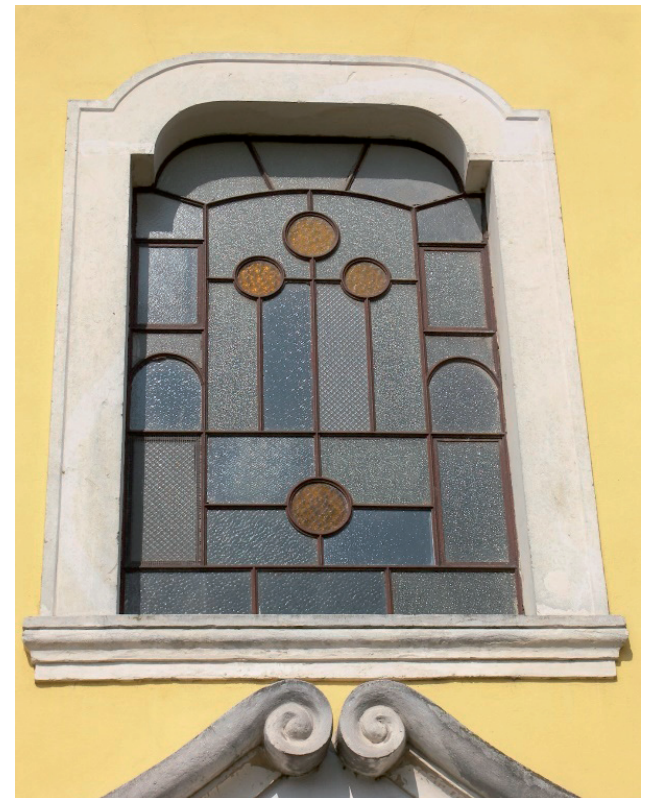

Slika 27. Prozor na glavnom pročelju prije radova

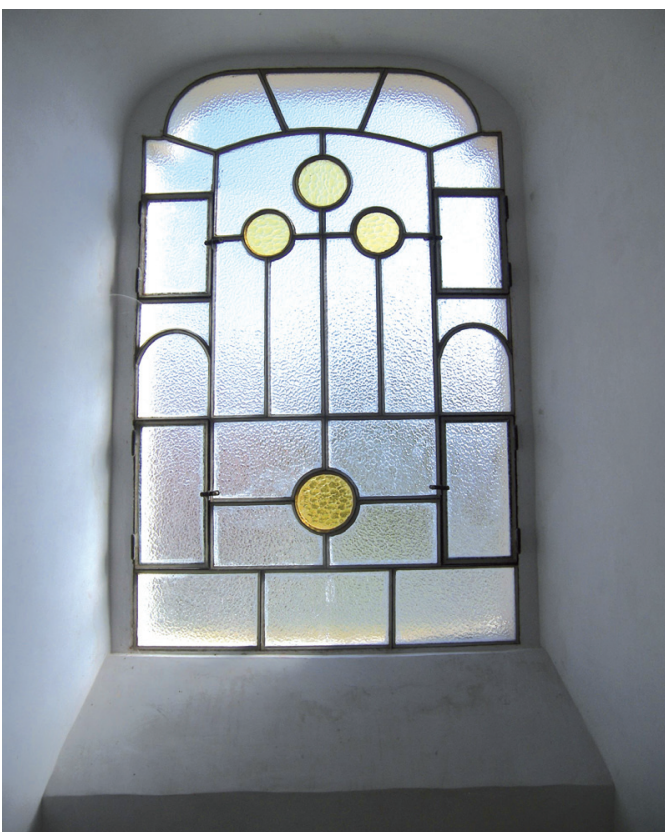

Slika 28. Prozor na glavnom pročelju nakon radova 
Po završetku opsežnih istraživačkih, građevinsko-obrtničkih i konzervatorsko-restauratorskih radova u kapeli, dijelovi glavnog oltara vraćani su postupno u prostor svetišta. U razdoblju od 2012. do 2015. godine postavljeni su donja zona glavnog oltara, predela, retabl, završni vijenac i atika. Radi što boljeg statičkog osiguranja poleđine donje zone glavnog oltara, u razini zidane menze ugrađena je drvena gredna konstrukcija pravokutnog oblika koja je preuzela dio težine predele, dijelova retabla i atike. Nakon montaže svih dijelova arhitekture, skulpture središnjeg dijela i atike glavnog oltara vraćene su na svoje pozicije.

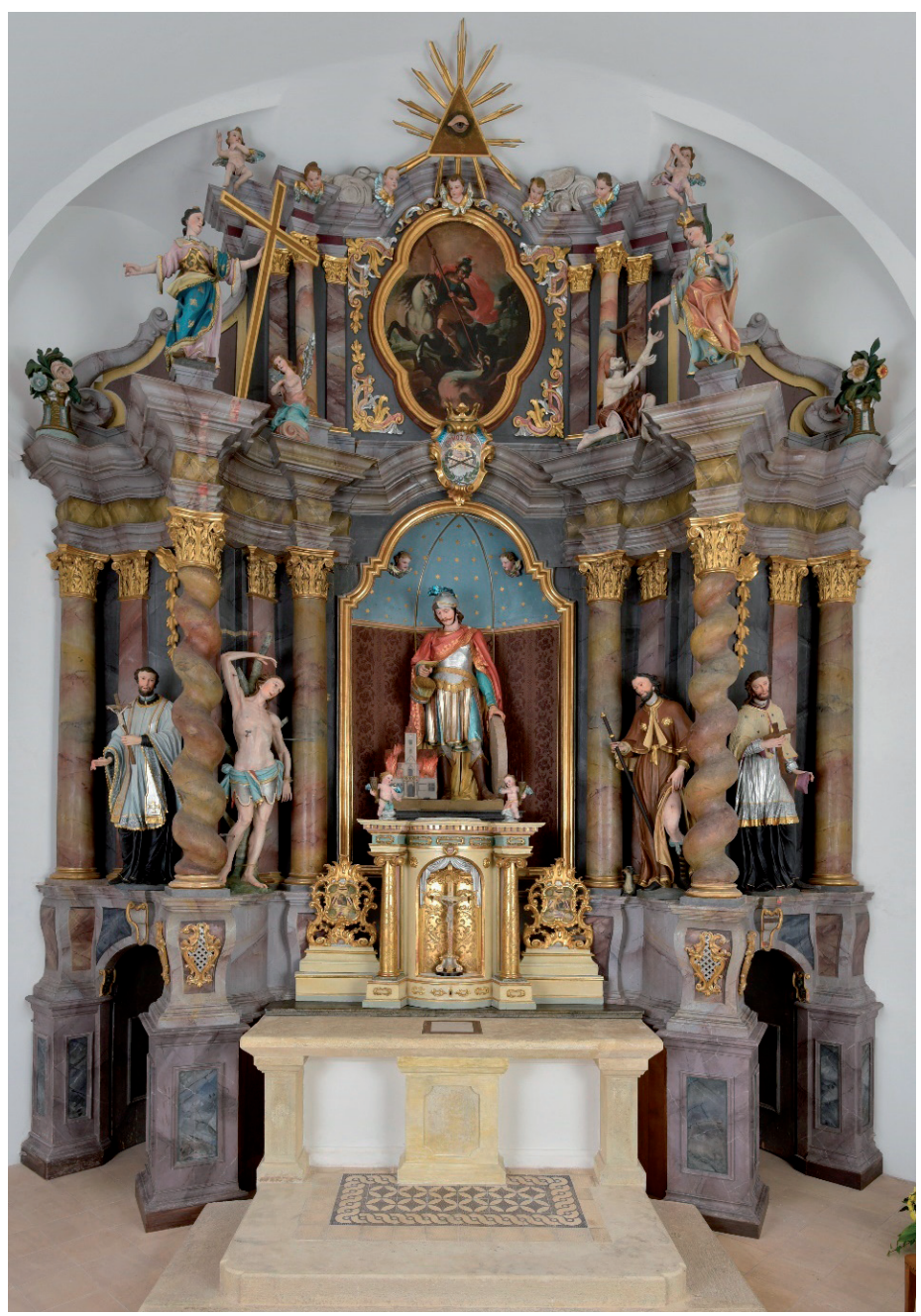

Slika 29. Glavni oltar nakon montaže 
U razdoblju od 2012. do 2017. godine Hrvatski restauratorski zavod organizirao je te dijelom izveo još i radove koje navodimo u nastavku. Na propovjedaonici su izvedene nove stube te je na njih vraćena stara ograda i oplata. ${ }^{72} \mathrm{Na}$ bočne oltare vraćeni su demontirani dijelovi bez restauracije. ${ }^{73} \mathrm{U}$ kovinopojasarskoj radionici $^{74}$ restauriran je kompletan, rijetko dobro očuvani barokni okov: baglame, petlje, kvake, brave i zaustavljači na vratnicama.

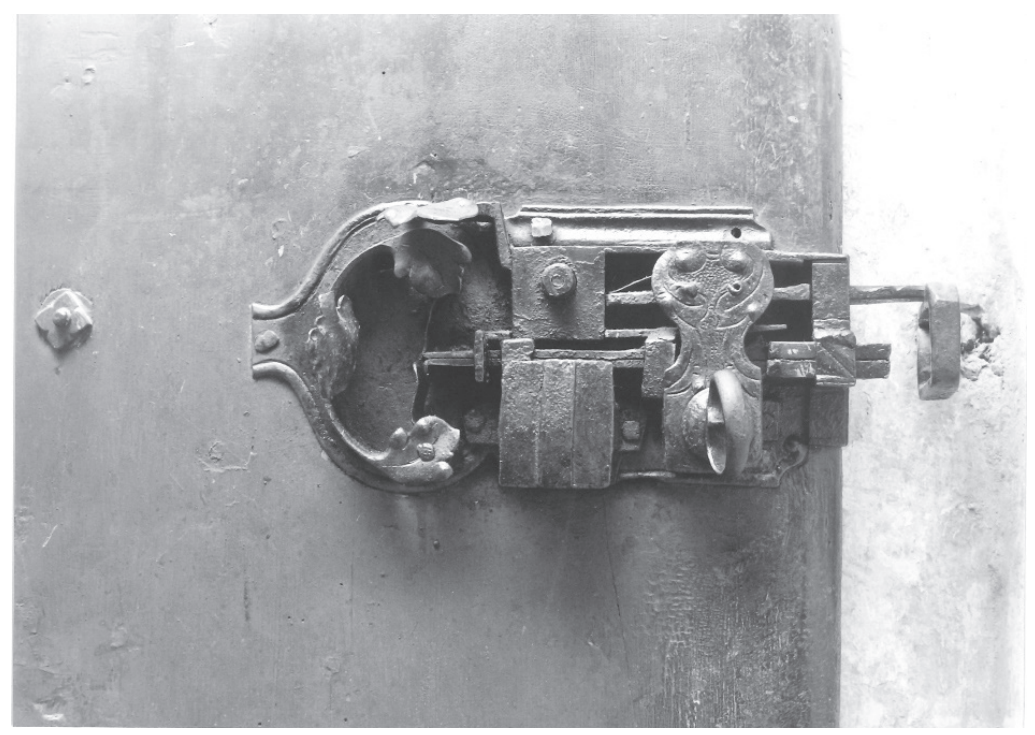

Slika 30. Detalj brave na vratima sakristije

Po uzoru na pronađene barokne kovane zidne svijećnjake izrađene su i montirane elektrificirane zidne svjetiljke. Obnovljena su kandila ispred glavnog i bočnih oltara. Južna vrata na lađi, kao i vrata u ulaznom prostoru koja vode na pjevalište, zbog lošega su stanja kompletno zamijenjena novima. ${ }^{75}$ Konzerviran je i djelomično restauriran oslik u kapelici Božjeg groba pod pjevalištem. ${ }^{76} \mathrm{Ob}-$

\footnotetext{
72 Orguljarska radionica Mihaljević d.o.o. iz Male Subotice.

73 Voditelj radova: Edo Anušić, Odjel za polikromiranu drvenu plastiku Hrvatskog restauratorskog zavoda.

74 Radovi: Kovinopojasar d.o.o. iz Zagreba; Davor Pintar Belina.

75 Vidi bilj. 60

$76 H R Z$, Odjel za zidno slikarstvo i mozaik, Radovi: Petra Uglešić, Miroslav Jelenčić.
} 
novljene su samostojeće kamene škropionice i škrabica. ${ }^{77}$ Izvedeni su konzervatorsko-restauratorski radovi na spiralnim stubama koje vode na pjevalište i u potkrovlje, na portalu na pjevalištu te na stubi pred glavnim oltarom. ${ }^{78}$ (Vremenom je spiralnim stubama klesanima od mekanog kamena izlizana hodna ploha, a imale su i niz krakelira zbog vibracija od gustog i teškog prometa oko crkve.)

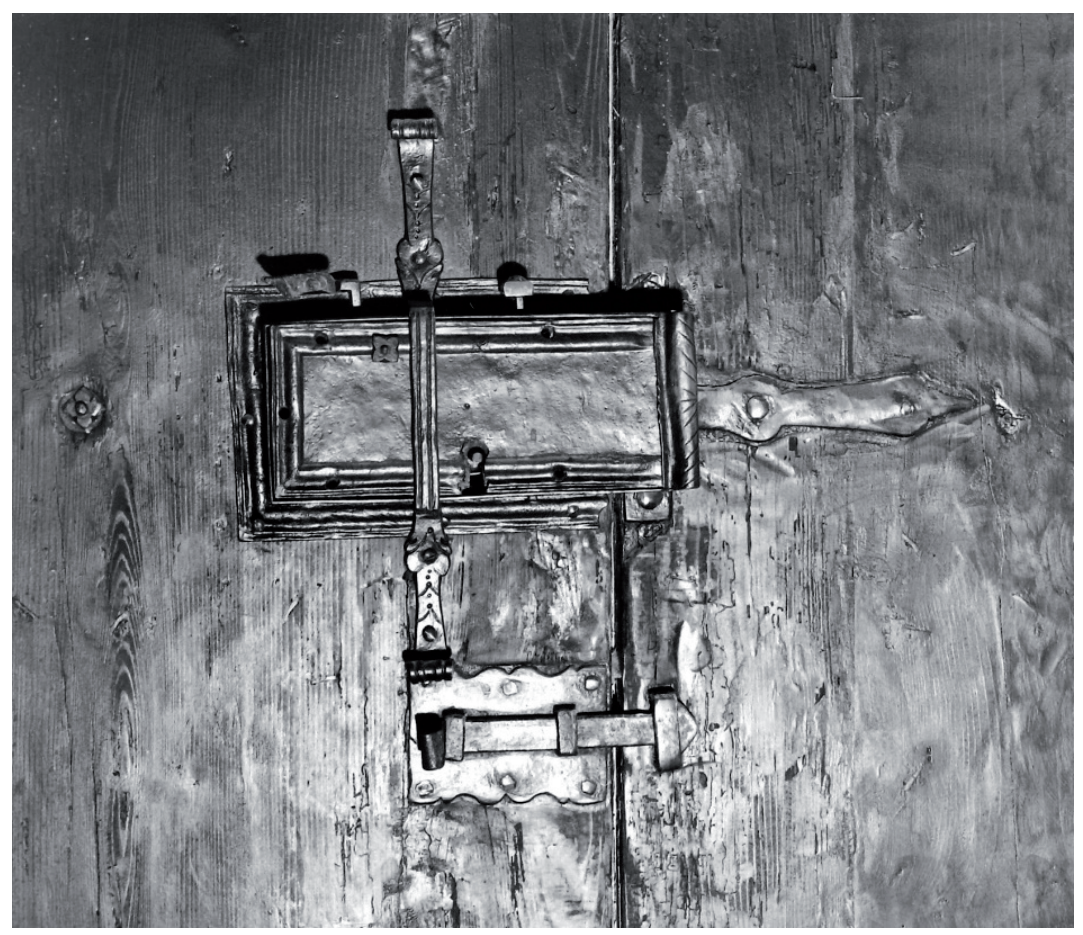

Slika 31. Detalj brave na južnim vratima u lađi

$77 H R Z$, Odjel za kamenu plastiku, Tomislav Svirac.

78 HRZ Odjel za kamenu plastiku, Tonko Fabris i Daniel Štimac. 




Slika 32. Spiralne stube s vidljivim krakelirama prije radova

U zvoniku su izvedene nove drvene stube, a na podeste su montirane nove mosnice. ${ }^{79} \mathrm{Na}$ posljetku, ${ }^{80}$ izvedeni su restauratorski radovi na očuvanim dvokrilnim drvenim vratnicama sa zaokretnim oknima i olovnim ostakljenjem iz 18. stoljeća kojima se iz kapelice Božjega groba ulazi u crkvu. ${ }^{81}$

79 Radovi: Euro-line d.o.o. iz Ludbrega.

80 Voditeljica programa zaštitnih radova je od 1995. godine Teodora Kučinac, HRZ, Odjel za graditeljsko nasljeđe. Radove je u ime Ministarstva Kulture RH, Uprave za zaštitu kulturne baštine nadzirao Konzervatorski odjel u Varaždinu, konzervatori: Željko Trstenjak, Ivana Peškan, Marijana Korunek i Vesna Juraga.

81 Radovi na drvetu: HRZ, Restauratorski odjel Ludbreg, Stanko Kirić,; Ostakljivanje: Vitraji Staab iz Zagreba, vl. Siniša Bačić. 
Restauratorske radove na orguljama na pjevalištu, najstarijim orguljama u Hrvatskoj iz 17. st. ${ }^{82}$ izvele su privatne radionice. ${ }^{83} \mathrm{~S}$ kućišta orgulja uklonjen je tirkizni preslik iz 1870. te je obnovljen dobro očuvani živopisni izvorni oslik.

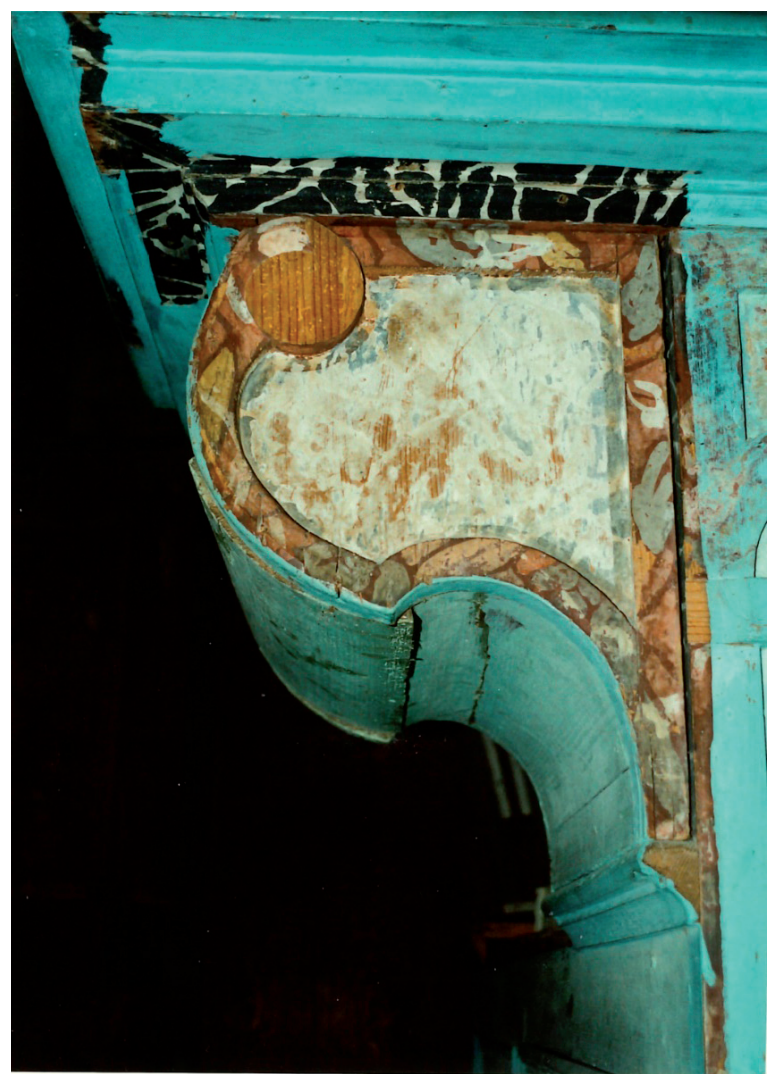

Slika 33. Restauratorska sonda na krilu kućišta orgulja

82 Jagoda MEDER, Orgulje u Hrvatskoj, Zagreb, 1992.

Ladislav ŠABAN, „Orgulje kapele Sv. Florijana u Varaždinu“, Vijesti muzealaca i konzervatora Hrvatske, Zagreb, 1971., br. 5, 25.-29.

Ladislav ŠABAN, „Evidencija orgulja u Hrvatskoj“, Godišnjak zaštite spomenika kulture Hrvatske, Zagreb, 1975., br. 1, 169.-177.

83 http://laudato.hr/ispisi-snimi.aspx?NewsID=16429 (2. 3. 2019.)

https://narod.hr/kultura/u-varazdinu-blagoslovljene-obnovljene-najstarije-orgulje-u-hrvatskoj (2. 3. 2019.)

Male orgulje s pet registara, prvotno građene za varaždinsku isusovačku crkvu (na sviralima se ističe godina 1644.), u crkvu sv. Florijana postavljene su oko 1780 . godine. Inicijator obnove je prof. Zdenko Kuščer, ravnatelj Orguljaške zaklade „Don Petar Nakić“. Svirala je obnovila Umjetnička radionica Hefferer iz Zagreba, a kućište privatna restauratorska radionica Velimira Ivezića iz Varaždina. 


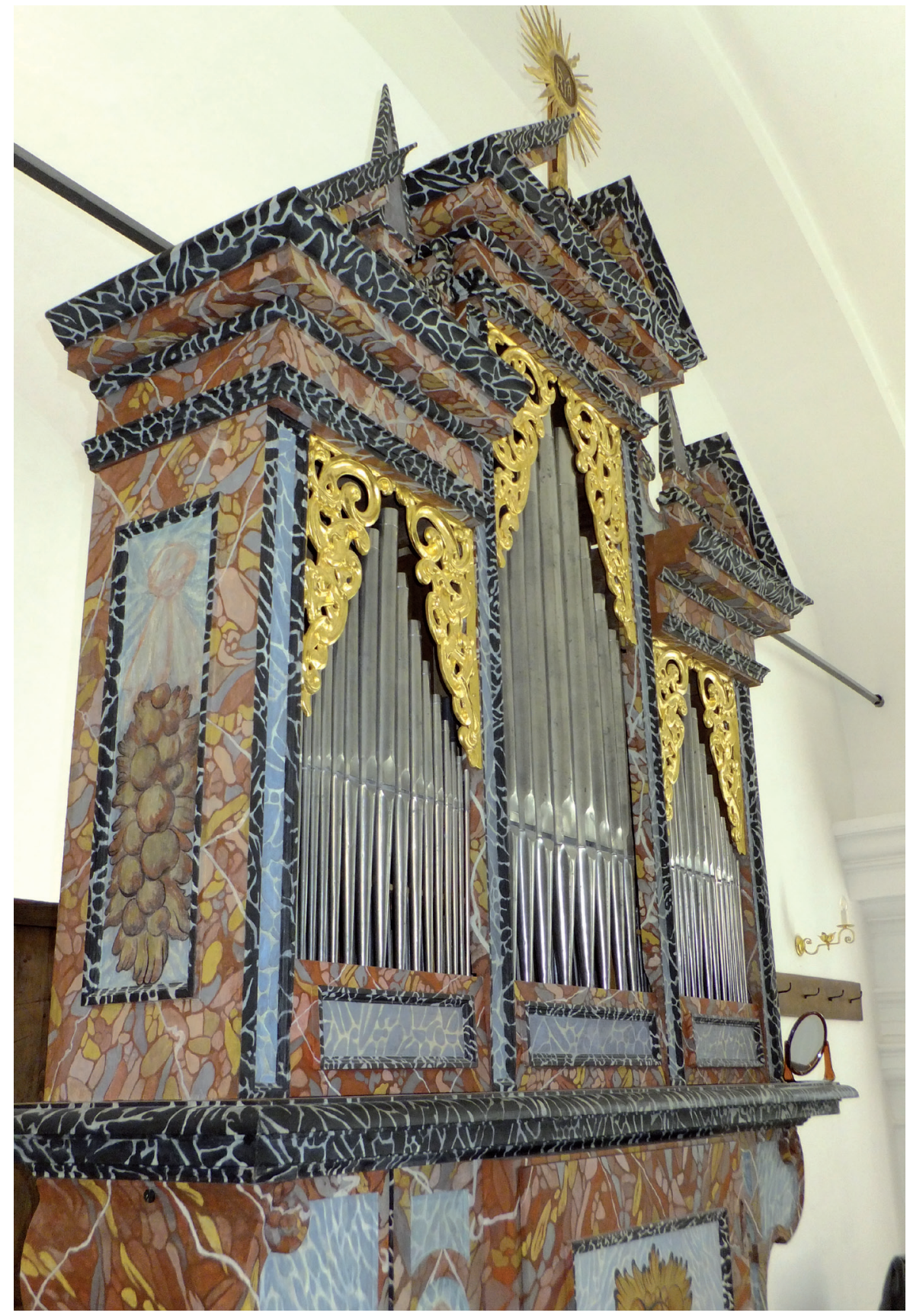

Slika 34. Detalj orgulja nakon restauracije 


\section{ZAKLUČAK}

Provedena konzervatorsko-restauratorska i arheološka istraživanja crkve sv. Florijana u Varaždinu potvrdila su arhivska istraživanja o slojevitosti njezine gradnje i upotpunila spoznaje o njezinom oblikovanju i visokoj razini umjetničkog obrta u Varaždinu u 18. stoljeću.

Ispod poda lađe očuvani su zidani temelji starije drvene kapele, građene sedamdesetih godina 17. stoljeća, a srušene 1733. godine.

Utvrđene su dvije glavne faze izvedbe pročelja današnje zidane kapele sv. Florijana. Pročelja starijeg dijela kapele, građenog između 1733. i 1738. godine, ožbukana su između 1748. i 1752. godine špricanom grubom žbukom tamnosive boje, a kao kontrast toj hrapavoj površini i tamnoj boji isticali su se pažljivo zaglađeni bijeli pilastri i vijenci koji su raščlanili pročelja lađe i svetišta na pravilna polja. Nakon požara 1776. godine formirano je novo glavno pročelje s raskinutim zabatom iz kojega izranja zvonik, a zidovi lađe su produljeni. Novo pročelje izvedeno je zaglađenom žbukom na kojoj se ističu kvalitetni klesarski, kiparski, štukaterski, slikarski i stolarski detalji. Ovaj sloj je ostao gotovo nepromijenjen u odnosu na vrijeme izgradnje zvonika krajem 18. stoljeća te je i obnovljen.

Konzervatorsko-restauratorska istraživanja interijera omogućila su jasno diferenciranje i valorizaciju dviju osnovnih faza uređenja toga sakralnog prostora. U drugoj fazi uređenja iz 1870. godine, zidovi i svodovi kapele oličeni su i oslikani imitacijom mramora i kamena u sivoljubičastim i sivoružičastim tonovima i ukrašeni geometrijsko-vegetabilnim ornamentima. Oltari i propovjedaonica također su tada obnovljeni na način uobičajen u 19. stoljeću - preslikavanjem preko izvorne polikromije i ponovnim zlaćenjem preko izvorne pozlate - te su svojim sivkastim mramorizacijama prilagođeni kolorizmu ziđa.

Istraživanja slikanih slojeva ziđa i svoda kao i slikanih slojeva drvenog inventara dala su dovoljno podataka za identifikaciju prve faze uređenja kapele, od 1738. do oko 1745. godine. Zidovi i svod bili su bijeli, oličeni vapnom, s iluzionistički oslikanim medaljonima i štukaturom na svodu. Izvorna polikromija oltara i propovjedaonice u toj je fazi bila slikana mramorizacija s crvenkastim, modrim, ljubičastim i ružičastim tonovima, s obiljem pozlate, posrebrenja i lazura. 


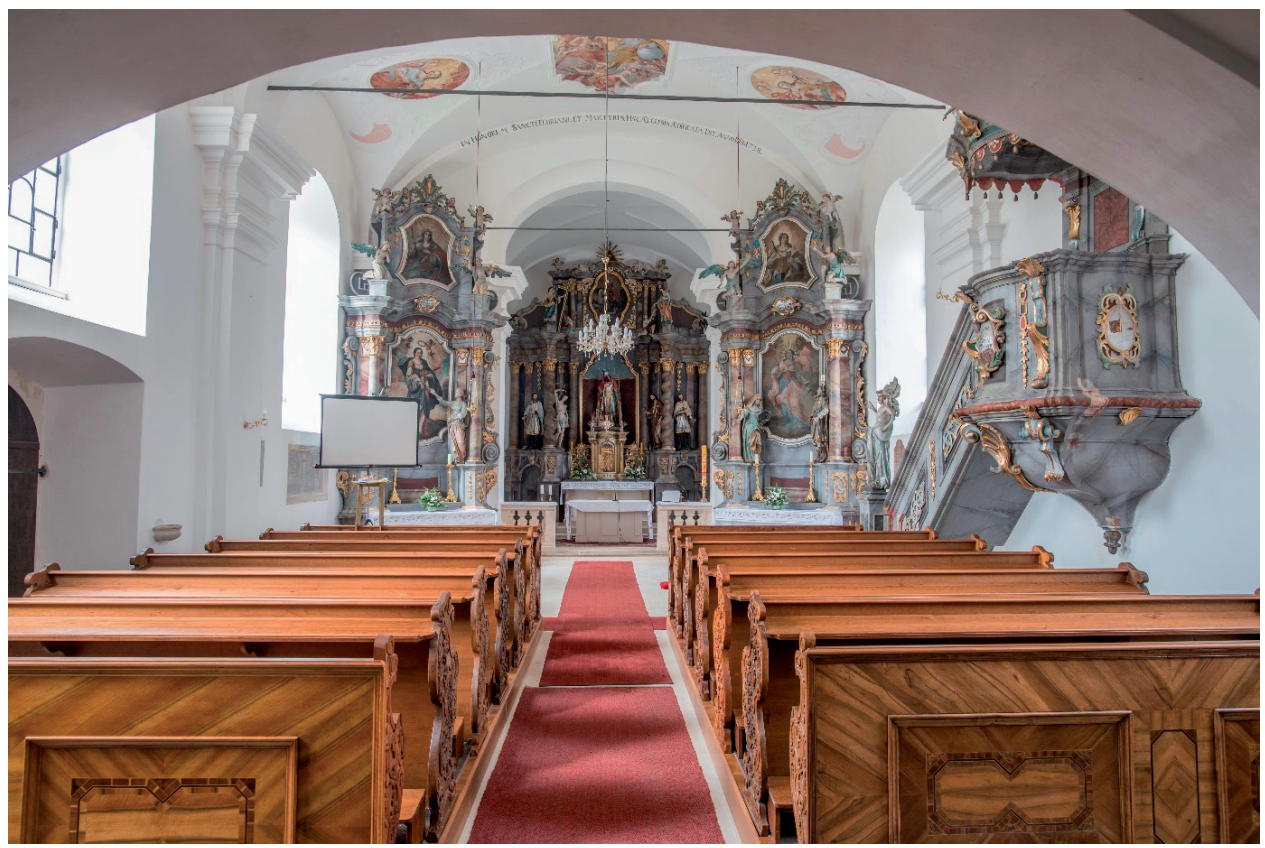

Slika 35. Unutrašnjost, pogled prema svetištu nakon radova

Interijer kapele sv. Florijana uređen 40-ih godina 18. st. pokazuje odlike kvalitetnog zrelog baroknog rješenja; u svijetlom, jasno artikuliranom dvoranskom prostoru skladno se nadopunjuju slikarski i kiparski ukrasi, govoreći o poznavanju i prihvaćanju suvremenih stilskih kretanja i tendencija, kako od strane varaždinskih majstora, tako i od građana, donatora ovih vrsnih umjetnina. Razrađeni i odlično izvedeni detalji drvenih klupa, popločenja ili okova govore o visokoj razini umjetničkog obrta u to vrijeme.

Kapela sv. Florijana, kao filijala smještena u predgrađu, bila je donekle pošteđena čestih i osobito radikalnih obnoviteljskih intervencija u unutrašnjosti, tako da ju je očuvanost i u određenom smislu intaktnost opreme činila jednom od najvrednijih i najinteresantnijih sakralnih prostora u Varaždinu. 


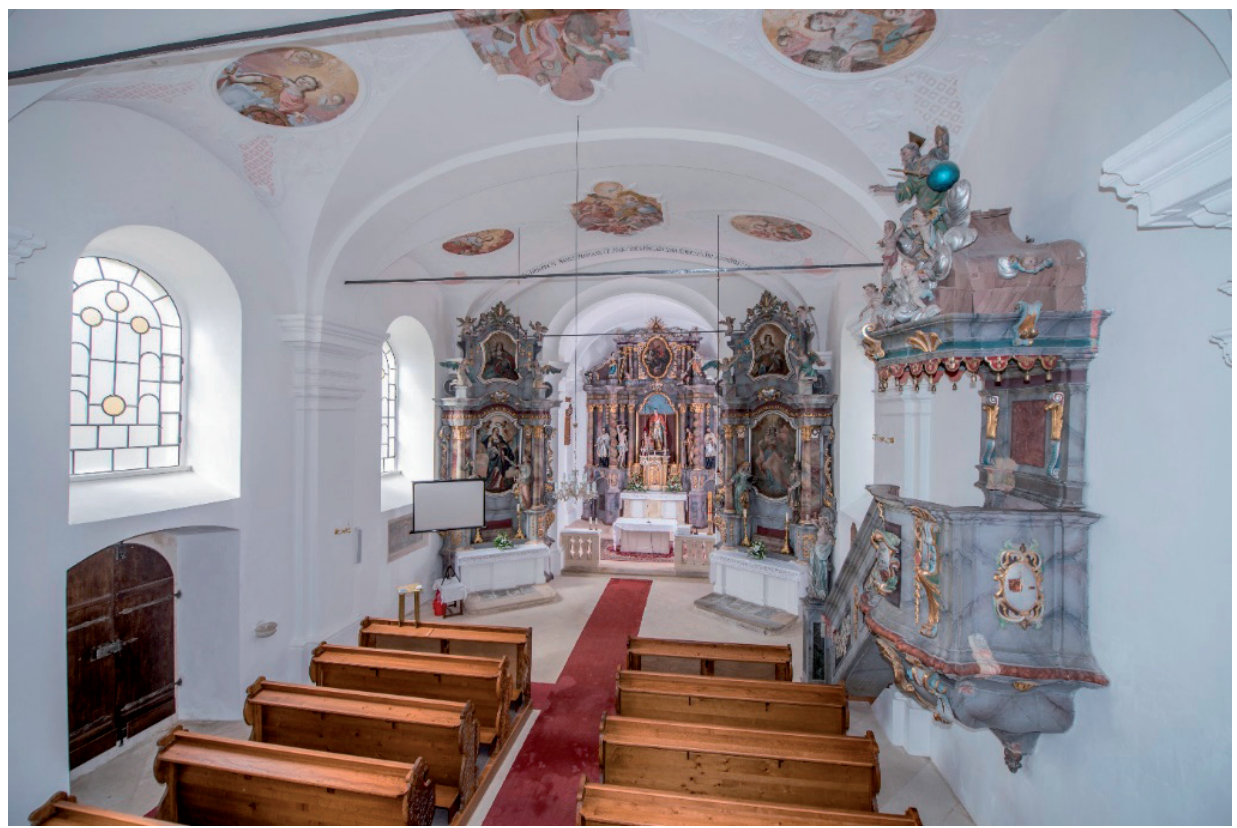

Slika 36. Unutrašnjost, pogled prema svetištu s pjevališta nakon radova

Interijer crkve sv. Florijana danas je ponovno svijetli prostor kakav je bio i u vrijeme izgradnje. Oslikani medaljoni na svodu prostoru daju žive naglaske, jednako kao i arhitektura inventara. Šteta je što dugogodišnja obnova nije bila popraćena i prvotno planiranim konzervatorsko-restauratorskim radovima na bočnim oltarima i propovjedaonici, koji bi pridonijeli cjelovitosti konzervatorskorestauratorskih zahvata i jedinstvenom skladnom oblikovanju interijera karakterističnom za ovu crkvu. 




Slika 37. Unutrašnjost, pogled prema pjevalištu nakon radova

\section{POPIS LITERATURE I IZVORA}

1/ Doris BARIČEVIĆ, Kiparstvo manirizma i baroka, Katalog zbirke "Sveti trag", Zagreb, 1994. 301.-340.

2/ Ivana DRMIĆ, „Rekonstrukcija i reintegracija slikanog sloja na svodu lađe u crkvi sv. Florijana u Varaždinu", Godišnjak Hrvatskog restauratorskog zavoda, Portal, 4/2013, Zagreb, 2013., 27.-35.

3/ Anđela HORVAT, Radmila MATEJČIĆ, Kruno PRIJATELJ, Barok u Hrvatskoj, Zagreb, 1982.

4/ Ivo LENTIĆ, „Varaždinski stolarski majstor Mathias Saurer", Vijesti muzealaca i konzervatora, Zagreb, 1968., br. 1, 5.-10.

5/ dr. Ivy LENTIĆ KUGLI, „Prilozi za istraživanje varaždinskih 'pictora' u 18. stoljeću (I. dio)“, Vijesti muzealaca i konzervatora Hrvatske, Zagreb, 1969., br. 3, 3.-12.

6/ dr. Ivy LENTIĆ KUGLI, „Nekoliko podataka o varaždinskim kiparima 18. stoljeća", Vijesti muzealaca i konzervatora, Zagreb, 1969., br. 4, 7.-16. 
7/ dr. Ivy LENTIĆ KUGLI, „Blasius Gruber pictor varasdiensis“, Vijesti muzealaca i konzervatora, Zagreb, 1970., br. 1-2, 13.-20.

8/ dr. Ivy LENTIĆ KUGLI, „Crkvene klupe varaždinskog stolara Matije Saurera“, Vijesti muzealaca i konzervatora, Zagreb, 1971., br. 2, 9.-11.

9/ dr. Ivy LENTIĆ KUGLI, „Građa za proučavanje varaždinskih 'pictora' u 18. stoljeću (II. dio)“, Vijesti muzealaca i konzervatora Hrvatske, Zagreb, 1977., br. 4, 36.-48.

10/ dr. Ivy LENTIĆ KUGLI, Varaždin, povijesna i urbana cjelina grada, Zagreb, 1977., 39.-40.

11/ dr. Ivy LENTIĆ KUGLI, Varaždinski graditelji i zidari 1700-1850, Zagreb, 1981.

12/ Željka LUKAČEVIĆ DOMINKO, Dimnjačarstvo i dimnjačari s posebnim osvrtom na grad Varaždin, Varaždin, 2017. - https://issuu.com/jimmy2k/docs/ dimnjacari_1 Published on Nov 26, 2017 (22. 02. 2019.)

13/ Jagoda MEDER, Orgulje u Hrvatskoj, Zagreb, 1992.

14/ Silvije NOVAK, „Izvještaj o konzervatorskim istraživanjima crkve sv. Florijana u Varaždinu“, Hrvatski restauratorski zavod, Zagreb, 1993., 1.-11., 15 fotografija

15/ Tajana PLEŠE, Varaždin - kapela sv. Florijana, Hrvatski arheološki godišnjak, 4 (2008), 165-167

16/ Gjuro SZABO, Spomenici grada Varaždina, rukopis u Gradskom muzeju Varaždin, 1919.

17/ Ladislav ŠABAN, „Orgulje kapele Sv. Florijana u Varaždinu“, Vijesti muzealaca i konzervatora Hrvatske, Zagreb, 1971., br. 5, 25.-29.

18/ Ladislav ŠABAN, „Evidencija orgulja u Hrvatskoj“, Godišnjak zaštite spomenika kulture Hrvatske, Zagreb, 1975., br. 1, 169.-177.

19/ Protokoli kanonskih vizitacija Arhiđakonata varaždinskog, knj. 161/II, 162/ III, 163/IV, 164/V, 166/VII, 167/VIII, 168/IX, 169/X, 179/XI a, 173/XIV, 175/ $\mathrm{XVI}$ - originalne knjige čuvaju se u Nadbiskupskom arhivu, Kaptol $31 \mathrm{u} Z a-$ grebu, a kopije na mikrofilmu dostupne su u Hrvatskom državnom arhivu (HDA), Marulićev trg 21, Zagreb.

20/ Fototeka i dosjei Hrvatskog restauratorskog zavoda - fotografije snimili i nacrte izradili: Iva Bartolić (slike 9, 10), Nevenka Belčić (slike 6, 7, 14), Teodora Kučinac (slike 25, 27, 28, 32, nacrt 4), Silvije Novak (slika 11), Tajana Pleše (slike 15, 16, nacrt 19) Vesna Šimičić (slika 33), Jurica Škudar (slike 3, 8, 12, 13, 18, 20, 22, 29, 30, 31), Natalija Vasić (slike 1, 2, 5, 17, 21, 24, 26, 35, 36, 37). 


\section{SAŽETAK}

\section{CRKVA SV. FLORIJANA U VARAŽDINU. REZULTATI KONZERVATORSKO -} RESTAURATORSKIH ISTRAŽIVANJA I PREGLED RADOVA (1992. - 2017.)

Crkva sv. Florijana smještena je na uskom povišenom platou, na sjevernom rubu staroga grada Varaždina, uz staru rimsku cestu iz Ptuja za Osijek ${ }^{84}$. Prilaz crkvi naglašavaju dva stupa sa skulpturama anđela. Glavno pročelje „,...konveksnom linijom osvaja gradski prostor. ${ }^{\text {} 85}$ Skladna jednobrodna nadsvođena crkva s nešto užim poligonalnim svetištem čuva vrijedan, kompletno sačuvan inventar iz doba baroka. Lađa je plitkim lezenama i širokim pojasnicama podijeljena u tri traveja. Nad ulazom u lađu je prostrano zidano svođeno pjevalište, oslonjeno na dva kamena stupa. Na pročelju i u unutrašnjosti ističu se pažljivo izvedeni i kvalitetni klesarski, kiparski, štukaterski, slikarski i stolarski detalji koji svjedoče o visokoj razini umjetničkog obrta u Varaždinu u 18. stoljeću.

Program zaštite i očuvanja ovoga kulturnog dobra koji je organizirao i vodio Hrvatski restauratorski zavod obuhvatio je arhivska, konzervatorsko-restauratorska i arheološka istraživanja, prijedlog prezentacije i projekt, a potom i građevinsko-obrtničke te konzervatorsko-restauratorske radove na pročeljima i u unutrašnjosti; na zidnim slikama, štukaturi, kamenu, metalu i drvenom inventaru. Pročelje je istraženo 1992. i obnovljeno 1995. godine, dok je unutrašnjost istražena 1997. godine, a opsežni zaštitni radovi izvođeni su od 2001. do 2017. godine. Istraživanjima na pročeljima ustanovljene su dvije značajne graditeljske faze: prva, iz polovice 18. stoljeća kada je sazidana kapela izvana ožbukana te druga, koja je i obnovljena, iz doba zidanja zvonika nakon požara 1776. godine. U dobro očuvanoj unutrašnjosti ustanovljene su također dvije cjelovite faze uređenja, prva iz 1738. - 1745. i druga iz 1870. godine. Prezentirana je i restaurirana oprema i slikana dekoracija iz prve faze, dok su oltari i propovjedaonica koji su i slikanom dekoracijom nekoć pridonosili osobitom skladu unutrašnjosti nažalost ostali u zatečenom izgledu iz druge faze kada su prilikom obnove unutrašnjosti preslikani. Obnovljena prozorska krila u crkvi i restaurirani zidni oslik u kapelici Božjega groba datiraju iz 19. stoljeća.

Ključne riječi: Varaždin; crkva sv. Florijana; barok; Blasius Gruber; Mathias Saurer; Johann Michael Taxner; Erber; Joannes Adam Poch; konzervatorsko-restauratorska istraživanja i radovi; Hrvatski restauratorski zavod.

84 Paškal CVEKAN, Djelovanje franjevaca u Varaždinu, Varaždin, 1978., 37.-39.

85 Anđela HORVAT, Radmila MATEJČIĆ, Kruno PRIJATELJ, Barok u Hrvatskoj, Zagreb, 1982. 


\section{SUMMARY}

\section{CHURCH OF ST. FLORIAN IN VARAŽDIN. RESULTS OF CONSERVATION AND RESTORATION RESEARCH AND REVIEW OF WORKS (1992 - 2017)}

Church of St. Florijan is located on a narrow raised plateau, at the northern edge of the Old Town of Varaždin, along the old Roman road from Ptuj to Osijek. The approach of the church is emphasized by two pillars with angel sculptures. The main facade captures the city space by convex line. The harmonious, singlenave church with a slightly narrower polygonal sanctuary contains a valuable, completely preserved inventory from the Baroque era. The facade and the interior are emphasized by stone carvings, sculptural, stucco, painting and joinery details, carefully executed and of high quality, that testify of the high level of artistic craftsmanship in Varaždin in the 18th century.

The program for the protection and preservation of this cultural monument, organized and managed by the Croatian Conservation Institute, included the archival, conservation-restoration and archaeological research, the project and the presentation proposal, the subsequent conservation of the construction and of the inventory as well as the conservation-restoration works on the facades and in the interior; on wall paintings, stucco, stone, metal and wooden inventory. The facade was researched in 1992 and restored in 1995, while the interior was researched in 1997, and the extensive conservation works took place between 2001 and 2017. Two major architectural phases were established on the facades: the first, from the mid 18th century, when the chapel was externally plastered and the second phase, which has been restored, from the time when the belfry was built after the fire in 1776. In the well-preserved interior, two complete phases of decoration were established, the first one from 1738 to 1745 and the second from 1870. The restored equipment and painted decoration from the first phase were presented, while, to our regret, the altars and the pulpit which, together with the paintings, contributed to the particular harmony of the interior, have remained unchanged in the appearance of the second phase when they were overpainted in a renovation of the interior. The restored window wings in church and wall paintings in the Chapel of God's grave date back to the 19th century.

Key Words: Varaždin; Church of St. Florijan; Baroque; Blasius Gruber; Mathias Saurer; Johann Michael Taxner; Erber; Joannes Adam Poch; Conservation and Restoration Research and Works; Croatian Conservation Institute. 